\title{
Subduing High Inflation in Romania. How to Better Monetary and Exchange Rate Mechanisms?
}

\author{
By: Daniel Daianu and Radu Vranceanu
}

William Davidson Working Paper Number 402

August 2001 


\title{
Subduing High Inflation in Romania. How to Better Monetary and Exchange Rate Mechanisms?
}

\author{
Daniel Daianu ${ }^{\mathrm{a}}$ \& Radu Vranceanu
}

- 22 August 2001 -

\begin{abstract}
Romania's overall economic performance during the first ten years of transition can be termed so far as disappointing: the country has not been able to deliver steady growth, low unemployment and low inflation. This paper focuses on the effectiveness of monetary mechanisms and policies during this period. Special emphasis is set on the exchange rate mechanism. The first part of the text develops a short introduction to relevant monetary theory in the transition context. In the second part, we analyse the stylised facts pertaining to Romanian economy and put forward some weaknesses of its banking system and monetary policies. The conclusion presents a set of recommendations for a reform of the going monetary policy.
\end{abstract}

Keywords: Monetary policy, Banking system, Exchange rate mechanism, Romania, Policy reform

\footnotetext{
* The research is carried out in the framework of a project sponsored by the World Bank and the IWW. The authors would like to thank Dorina Antohi, Anca Paliu and Surica Rosentuler from the National Bank of Romania for their cooperation in getting useful data, as well as Damien Besancenot and André Fourçans for their helpful remarks on a first draft. A preliminary version circulated as a CEROPE Working Paper, $\mathrm{nr}$ 21, September 2000.

a) Academy of Economic Studies and Romanian Center for Economic Policies, Bucharest. E-mail: ddaianu@rnc.ro.

b) ESSEC, Department of Economics, BP 105, 95021 Paris-Cergy, France. E-mail: vranceanu@essec.fr
} 


\section{Introduction}

In Helsinki, in December 1999, Southeast European countries like Bulgaria and Romania were invited to start admission negotiations with the European Union. Although an official accession date has not yet been decided, a realistic forecast would set it around the year 2010. By this date they will face the monetary integration challenge, a process that may last a few more years. In the current decade, these countries should undertake important structural transformations in order to set their economies in line with Western ones. Fast integration requires the fulfilment of a set of social, political and economic criteria. Essential economic criteria are a low inflation rate, low public debt and deficits, low interest rates and a stable currency against the Euro. Less explicit, but also very important, these countries should reduce gaps vis-à-vis the Western partners, in order to be able to comply with obligations related to the participation to the Western club. A relatively high GDP per head is by all means the best ticket to entry.

Unfortunately, given a limited number of instruments and resources, these goals may sometimes be conflicting and policy choices should take into account the trade-off between them. Also, during the decade, the relative importance of the various objectives may change and would require an adjustment of policies and mechanisms.

In most developed countries, the management of monetary parameters and the exchange rate is the responsibility of central banks. Sometimes the central bank determines on its own the policy objectives to be achieved, some other times the government has a say in this process. Following the Fed example, in the last twenty years, all developed countries have endowed their central bankers with powerful tools that allow them to control the key variables in the money market. This was the full truth about setting "independent" central banks: not only to give central banks political independence, but also to cut any direct link between state deficits and monetary base. The significant progress of the Western world in the fight against inflation can be attributed to a large extent to the implementation of more efficient mechanisms for controlling money supply.

Macroeconomic performances depend also on the design and goals of the exchange rate mechanism. One may order exchange rate mechanisms in keeping with the cost of changing the parity from the most to the least rigid: dollarisation or euroisation $\rightarrow$ currency board regimes $\rightarrow$ credible peg (or fixed rate) $\rightarrow$ non-credible peg $\rightarrow$ managed float $\rightarrow$ fully flexible rates. The 1997 Asian crisis has much eroded the confidence of policymakers in the developing world in the virtues of fixed rates and other crawling pegs under the current international financial arrangements and rules. It also put forward the increased scope for speculative lending and speculative currency attacks in a world of increased capital mobility (Krugman, 2000). Not only modern communication technology allows very rapid international transfers of funds but also, in the context of a liberalisation Zeitgeist in the late 1980s and the early 1990s, both developed and many developing countries have removed all/most of capital controls and restrictions in the last twenty years.

Whereas flexible managed rates is still the rule in practice, there is a rising advocacy of super-fixed exchange rate mechanisms - against the background of rising discontent with the working of the international financial system. Some economists favour currency boards (Rivera-Batiz and Sy, 2000; Gulde, Kähkönen and Keller, 2000) and even dollarisation (Berg and Borensztein, 2000; LeBaron and McCulloch 2000). Gulde, Kähkönen and Keller (2000) argue that Eastern European countries 
should adopt currency boards not only during the intermediate period before joining the EU, but should also maintain this mechanism during the two-year test period which precedes the adoption of the single currency. ${ }^{1}$ Under such arrangement, in a world of increased capital mobility, the country actually transfers the control over monetary policy into the hands of the central bank issuing the reference currency (that is, the Fed or the ECB). That would allow the small country to "import" the credibility of this institution.

The basic rationale against fixed exchange rate regimes may be traced back to the pioneering work of Milton Friedman (1953). According to his view, when a country is hit by an adverse and specific output shock, the real exchange rate should depreciate to restore competitiveness. While this may be achieved by a reduction in the domestic price level, the price adjustment process may be too costly or too slow; an adjustment of the nominal rate would achieve the same result less harmfully. In the same line of reasoning, super-fixed exchange rate regimes may not be consistent with the smooth structural real appreciation of the currency required by the would-be productivity catch-up in the sector of tradable goods (Halpern and Wyplosz, 1997 develop on the Belassa-Samuelson principle as applied to transition economies).

One should notice that fully flexible rates are more a theoretical construct than a real life experience. Indeed, central banks firmly supporting this principle, like the Fed or the National Bank of Japan, and more recently the ECB, are far from letting their currency being determined by market forces only. As put forward by Calvo and Reinhart (2000), they follow some kind of "managed float" regime, given that the monetary policy is not indifferent to changes in the international value of the domestic currency. This leads to a relatively low variance in the exchange rate and a higher variation in reserves and short-term rates. The two authors argue that sometimes the difference between "managed float" and "not-credible peg" is quite negligible. Under a not-credible peg, the government announces an exchange rate target, but would discretionary change it, quite frequently.

This paper aims to introduce some basic elements of an analysis of monetary and exchange rate policies, from a perspective related to the economic reality of Southeast European transition economies; it analyses the role played by monetary policy in Romania so far, the factors that contributed to poor inflation performances and suggests some possible ways of improving the effectiveness of its monetary policy. Special emphasis is placed on the relationship between monetary policy and the exchange rate regime. The paper has a clear macroeconomic and financial bias. Of course, many microeconomic, institutional, political and cultural factors may have been brought into the picture, as there are many relevant variables during such a complex phenomenon as transition. But focusing on one dimension at one time would limit the risk of hiding or omitting the essential mechanisms and relationships. In particular, it should be noticed that the paper does not explicitly address the question of slow growth in Romania. If we implicitly assume that moderate inflation and a stable currency could favour growth, other aspects, as the relationship between investment and savings, the improvement of Romanian firm competitiveness in the world market, the resource reallocation toward dynamic firms and sectors are not dealt with.

The next section briefly recalls some basic difficulties that policy reform faced at the beginning of the transition process in the most centralised economies. Section 3

\footnotetext{
${ }^{1}$ It is however not obvious which would be then the role of this test period, if the exchange rate reveals no information about economic performances and policies.
} 
comments on the relationship between monetary and fiscal discipline under various exchange rate mechanisms. Section 4 analyses the risks of speculative attacks that may occur under fixed exchange rates regime. Sections 5 to 9 analyse in depth the Romanian monetary and exchange rate mechanisms and point to the main factors that harmed the effectiveness of the disinflation policy in the late nineties. The conclusion and some policy implications are presented in the last Section.

\section{FIRST PART: THEORY}

\section{Inflation and monetary policy in a centralised transition economy}

At the beginning of the transition process, many international experts and organisations viewed the basic transition economy as a standard economy hit by a large adverse supply shock, which have to solve simultaneously a problem of monetary overhang and of declining output. Ten years later, everyone seems to agree that the initial approach to reform in these countries built on over-simplified representations of the reality. Some older and recent criticism has put forward the intrinsic ineffectiveness of orthodox reforms in highly disorganised economies and advocate the need to enforce "institutions" (the state and the market included) as a necessary precondition to successful reform (Blanchard, 1997; Stiglitz, 1999; Rodrick, 1999).

In this section, we would like to briefly comment on the factors that might have justified a doze of chronic inflation during the first years of transition (different from the corrective inflation that accompanied price liberalisation in a context of monetary overhang). We describe a hypothetical economy, whose fundamental features are emphasised in an extreme way. The basic framework refers to a country that did not benefit from early programs of partial and gradual reform in the late 1980s. The purpose of this section is to tell the inflation story in a straightforward way, then to investigate whether this story is still true.

Formerly socialist economies were highly centralised: in general, a given commodity or service was produced by a few huge state-owned firms; some commodities were produced by only one firm and sometimes, a given firm had only one buyer for its products. (Such organisation made central plan easier to be set up). Imagine then the chain of production of a final consumption good. If one of the firms got out of the market, the whole chain would collapse. Of course, this is quite an extreme characterisation, but it is not a very unrealistic picture for highly centralised countries like Romania, Bulgaria or Russia, at least at the beginning of the transition process. Intuitively, one may see then why governments were keen on letting burst some of the firms.

To produce, firms need energy and other inputs. While the other inputs are produced at home, energy is bought in the world market (of course, some other essential inputs would also be bought overseas). Thus, any devaluation would have deteriorated the balance sheet of the representative firm. If the capital market is not functioning well, the representative firm will not be able to borrow against future income and would buy less of the other inputs. Consequently, the devaluation would imply a reduced output and even the exit of the firm of the market. In order to avoid the collapse of production chains, governments in transition economies have initially subsidised the firms in trouble (gave them money or blocked energy prices). The increased public deficit was in general financed by the central bank. Often with a lag, the consecutive increase in money supply led to an increase in prices, which put 
additional pressure on the exchange rate. Even if the central bank had striven to keep the parity constant, the loss of competitiveness entailed reserve depletion and, in the end, the currency has to be devalued. A new inflation cycle is at work.

Today, the economic landscape has changed much. Most governments have banned direct subsidies to firms. However, in the less advanced countries along the reform path like Russia, Ukraine, or Romania, there is still a massive problem of tax arrears, where the government tolerates the accumulation of unpaid taxes of the firms that seem to face financial difficulties. The resulting deficit is in general monetized, either directly or through the commercial banks that would refinance themselves against treasury bonds as collateral. In addition there is a "hunger" for inflation, as the latter becomes a perverse way of stabilising arrears in real terms, for otherwise the economy would suffocate itself by not being able to pay wages and critical inputs.

One may argue that the rationale for firm support has not changed: there would be still a need to keep some firms in the production chains under perfusion, given a risk of overall collapse. However, the old argument has lost much of its force today. Firstly, increased international openness allowed foreign suppliers to become a sensible alternative to domestic firms. More important, transition economies have undertaken an important process of de-monopolisation: many private firms have entered the market and are today serious competitors for former national champions. Capital markets have also widened and deepened, thus providing firms that face temporary payment difficulties the needed relief. In this context, an inefficient supplier may be replaced at a relatively low social cost (i.e. there would be no undesired spillover).

While at the origin of the inflationist cycle stood the will of the government to protect the weak firms, today the initiative seems to sit with the firms themselves, which, in a quest for tax exemptions, try to hide the true costs and claim the state support. This non-cooperative strategy is dominant, insofar as the firm which does not play defection in the arrears game will be penalised (Daianu and Vranceanu, 2000). One could notice that this vicious circle that perpetuates inflation, tax arrears and a weak currency could also be related to lack of progress with restructuring and slow resource reallocation, factors that hamper long-term growth.

As an upshot, consistent and well designed monetary and exchange rate policies and mechanisms, backed by additional structural and institutional reforms, could help today terminating inflation and inflation expectations without putting additional strain on the productive sector.

\section{Monetary discipline, fiscal discipline and the exchange rate mechanism}

As mentioned in the introductory section, in the last few years, notably after the 1997-1998 Asian and Russian financial crisis, an increasing number of economists argued that the recourse to super-fixed exchange rate mechanisms, like currency boards and, more extreme, dollarization (euroization) would allow the countries victims of high inflation and excessive currency instability to import the discipline of the reference currency.

In the past, currency boards were mainly to be found in the UK colonies. Today, only a few countries use such schemes (to mention only Argentina, Hong

\footnotetext{
${ }^{2}$ In Romania, by mid-2000 tax and inter-firm arrears were more than 35\% of GDP. When firms use actual liquidity for paying wages and some taxes, inter-firm arrears emerge as temporary quasi-inside money, which also fuels inflationary expectations (Daianu, 1994). See also the study of Pinto et al. (2000) on tax arrears in Russia.
} 
Kong, Bulgaria and Estonia), in general as a solution of last resort to excessive price and financial instability. Under a currency board, a fixed conversion rate between the local currency and a foreign one is decided and the domestic monetary base (cash and bank deposits) is $100 \%$ (and more) backed by low risk assets denominated in the foreign currency. The currency board has no right to issue central bank money against any domestic assets.

In general, currency boards have contributed to bring down high inflation quite fast, but recorded less impressive results in terms of stabilising output in the aftermath of major adverse shocks (Chang and Velasco, 2000). The major difficulties faced by Argentina after the 1998 crisis until today (July 2001) point at the main risks associated to currency boards. Pegging the peso to the dollar helped Argentina to bring down inflation sharply. The reverse of the medal comes with dollar appreciation at the end of the nineties. This deteriorated strongly Argentinean competitivity on Latin American markets, in particular with respect to Brazil, its main competitor. With falling exports, despite the slow growth recorded in 1999 and 2000, the trade deficit increased and required increasing external financing. Although devaluation did not seem possible, investors become increasingly nervous about the possibility of the Argentinean government to service its debt. In June 2001, the government, supported by the IMF, managed to convert some short term into long-term debt, and by July, the peg to the dollar was partly relaxed (exporters get a subsidy, while importer pay a tax); it is also planned to use as reference money a synthetic currency, composed of dollars and euros. But the risk of liquidity has not yet disappeared. As an upshot, Argentinean experience emphasises that a small country takes major risks from pegging its currency to a country which is not its dominant trading partner, even if devaluation is not an option.

Bulgaria adopted an idiosyncratic ${ }^{1}$ currency board in July 1997 as the main building block of a resolute stabilisation programme. Inflation fell dramatically, from $580 \%$ in 1997 to less than $1 \%$ in 1998 . Although the growth rate was of some $3 \%$ per year during the period 1998-2000, the unemployment rate has kept on increasing, to reach $18 \%$ in 2000.5 Another major risk for Bulgaria is related to the large and increasing foreign debt.

Gulde, Kähkönen and Keller (2000) point that by ruling out the possibility to finance the deficit by money creation (that is, no central money can be issued against treasury bonds), a currency board would set a strong constraint on spendthrift governments and would bring about more fiscal discipline ${ }^{6}$. This argument applies as such for closed economies, but less so in a global environment, according to the famous Mundell-Fleming paradigm.

Let us consider two identical countries, with the same initial fiscal stance and the same risk of default on the sovereign debt. One country has a currency board, the other a central bank under a fixed exchange rate mechanism. We assume that under a currency board the devaluation risk is zero (but the rationale would not change if we

\footnotetext{
${ }^{3}$ Under dollarization, the country loses the seigniorage income, but the credibility of the fixed parity is much increased, given the very high costs of reversing the process.

${ }^{4}$ The Bulgarian monetary institution lacks an important feature of basic currency boards. The government account is held at the Currency Board. In case of a deficit, this would lead automatically to an increase in the monetary base. See Miller (1999).

${ }^{5}$ By not underestimating the size of unemployment, this should not necessarily be seen as a signal of poor performance: the impossibility of the central bank to lend to the government has limited the spending possibilities of the government and, thus, put an end to state subsidies to under-performing firms. In turn, this may have pushed with much needed restructuring.

${ }^{6}$ But not necessarily financial discipline in the economy, where firms may continue to run big arrears.
} 
assume that it is only lower than under fixed rates). Additional public borrowing involves small increases in interest rates above the world rates, which would lead to inflows of capital. This additional foreign capital not only allows financing the deficit but also would increase the currency reserves of the board, the monetary base and the money supply. The automatic response of the currency board consists in accommodating any increase in public spending. Ceteris paribus the public deficit and the current account deficit increase in pair.

Under a fixed exchange rate regime, and under imperfect information of private agents on policymaker's priorities, a government truly committed to zero devaluation policy is in a worse situation than with a currency board. While this government still cannot have an autonomous monetary policy, the risk of devaluation is positive and adds as a premium on interest rates. This discourages investment, output and employment and further increases the devaluation risk. For a given fiscal deficit, gutput is lower under fixed exchange rates than under the currency board regime. 7

To sum up, under a currency board, monetary policy cannot be used to foster demand and employment, but fiscal policy is a powerful expansionary instrument. High unemployment countries, like those from Southeast Europe may thus be tempted to recourse to the fiscal stimulus in order to reduce high unemployment, but this endeavour may prove detrimental over the longer term if it undermines overall policy credibility (due to too high public deficits and related high interest rates). In addition, by the moment of the accession to the EU, successive periods of high deficits may raise a problem of debt and debt reduction, hard to be tackled in one stroke. There is another risk that would occur if governments rely too much on fiscal polices; as suggested above, above a certain level of indebtedness, the default risk can become significant and further penalise investment and growth. To counter these risks, additional limits on fiscal deficits, of the kind laid down in the Maastricht Treaty, should be enforced. But these would leave governments empty hands in face of asymmetric shocks and associated increases in unemployment.

With fully flexible rates, the government has no incentive to recourse to the fiscal stimulus, given that it can only crowd-out exports in an equivalent amount. So it can freely follow a low deficit fiscal strategy and stimulate activity by increasing the money supply. This will put downward pressure on interest rates, which stimulates investment and tends to depreciate the currency, which in turn fosters exports, at least in the short run. As a partially offsetting effect, this depreciation is taken into account by foreign investors who require a depreciation premium. By the moment of the accession, the recourse to devaluation will no more be allowed, but hopefully, the economy would have grown enough.

Of course, the main risk arising from an incautious recourse to monetary expansion is to fuel inflation. The risks are higher in those transition economies where soft-budget constraints are still the rule rather than the exception. In such countries, injections of liquidity would rapidly transform in price increases and would have little impact on portfolio choices. The weak response of interest rates would then explain a modest output increase. Thus, structural reforms and the enforcement of firm hardbudget constraints are a basic precondition for monetary policy effectiveness.

So far, we have shared with supporters of currency boards the implicit

\footnotetext{
${ }^{7}$ In a dynamic perspective, maintaining the zero devaluation policy for a long period may help reducing the risk, as people update their expectations downwards (Besancenot, Vranceanu and Warin, 2000). In turn, this improves the employment performance of the economy. But a strict rule of nodevaluation like the currency board still brings a better result.
} 
assumption that such an institution would almost eliminate the risk of currency attacks. In the next section we take a critical look to this issue.

\section{Speculative attacks and currency boards}

\subsection{First generation models: arguments pro currency boards}

A well-known explanation to currency crises under a fixed exchange rate regime was worked out by Salant and Henderson (1978), Krugman (1979) and Flood and Garber (1984). The law of one price governs the price level in the small country, while the price level of the foreign country is given. The uncovered interest parity also holds. These "first-generation models" postulate an exogenous increase in the central bank domestic credit (Flood and Marion, 1999). The subsequent increase in money supply puts downward pressure on interest rates and entails a capital flight. In order to defend the parity, the central bank must sell reserves such as the total amount of high-powered money is kept constant. At some moment in time, its reserves will be totally depleted and the fixed rate regime must be abandoned. Holders of domestic currency realise that the policy is unsustainable and force the exit from the fixed exchange rate arrangement before the moment when the reserves are completely depleted.

In the case of a currency board, the monetary base has no other counterpart than the reference foreign currency. Thus, such a monetary institution cannot create money by increasing credit to banks or to the government. In the line of the former analysis, many experts suggest that this institutional arrangement could completely rule out the risk of a currency attack. This certitude should be twice qualified.

\subsection{Currency boards, the Phillips curve and output cycles}

It may be argued that in the short and medium-run, prices in transitional economies are driven by the wage costs given the stance of the labour market. Indeed, in these economies, the productive sector is dominated by large firms, which often hold a monopolistic position. Such firms may form prices simply by adding a profit margin to unit costs. Then, for constant productivity, there is a straight relationship between wage and price inflation. At some moment in time, for a given level of unemployment, prices and wages would chase each other upward. Inflation is therefore positive if unemployment falls below its structural value. 10 This alternative logic may explain a loss in competitiveness that does not build on the assumption of exogenous increase in central bank domestic credit.

Starting from an initial situation with positive inflation, at some moment in time, domestic prices will exceed the world prices and net exports will become negative. As a consequence, aggregate demand diminishes and investment profitability deteriorates. Private capital inflows decline or are reversed. The reserves of the currency board begin to fall; simultaneously, the money stock is reduced. The

\footnotetext{
${ }^{8}$ Some authors part with the law of one price and write an equilibrium condition in the money market that establishes a positive relationship between the money stock and the domestic price level.

${ }^{9}$ The optimal timing requires no discrete jump in the price level (i.e. an infinite inflation rate). Therefore, the currency attack should occur when the actual fixed rate and the implicit exchange rate that would clear the market under a flexible scheme (the "shadow" exchange rate) are equal (Flood and Garber, 1984).

${ }^{10}$ This is quite a traditional explanation, which can be traced back to the paper by Samuelson and Solow (1960). See for a modern reference Layard, Nickell and Jackman (1991).
} 
equilibrium output declines further on. At some moment in time the decline in output should be large enough (and unemployment high enough) such that prices start to decline; the reverse process is at work.

A simple model helps describing the mechanism more precisely. Let the price equation be a standard Phillips-curve:

$$
\frac{d p(t) / d t}{p(t)}=\gamma[y(t)-\bar{y}]
$$

where $\bar{y}$ is the structural output, i.e. the output level associated to the structural unemployment rate (alternatively, one may carry out this reasoning in output growth rates instead of levels). Structural unemployment is related to various wage rigidities and frictions. Notice that in transition economies, this structural rate of unemployment may be quite high.

Let us denote by $R$ the reserves of foreign exchange of the currency board, by $p^{*}$ the price level in the EU and by $\bar{e}$ the official exchange rate. Then, reserves will follow the dynamic:

$$
\frac{d R(t) / d t}{R(t)}=\alpha[\bar{e} p *-p(t)]
$$

The equilibrium output will respond to the contraction in exports and the money stock according to:

$$
\frac{d y(t) / d t}{y(t)}=\theta \frac{d R(t) / d t}{R(t)}
$$

Thus equation (2) can be written as:

$$
\frac{d y(t) / d t}{y(t)}=\alpha \theta[\bar{e} p *-p(t)]
$$

The price level and output motion laws are solutions to the system of differential equations (1) and (4). One has noticed the similarity between this model and the famous Predator-prey model. There is a non-trivial stationary point $E$ of coordinates $(\hat{y}=\bar{y}, \hat{p}=\bar{e} p *)$. As can be easily observed from the phase diagram (Figure 1), prices and output display cycles around the equilibrium point. That is, starting from any other initial point except the stationary point, the price and output solution belongs to a closed loop (one of the possible paths is depicted in Figure 1, where the arrows indicate the sense of motion).

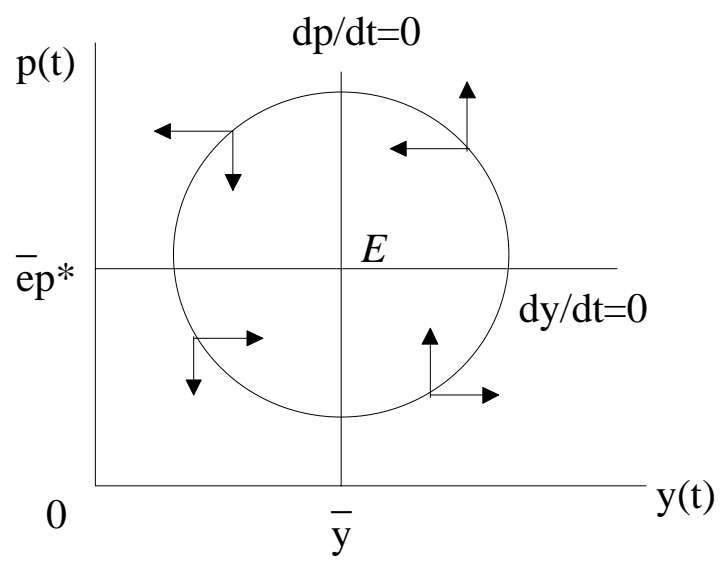

Figure 1: the Phase diagram

Let us imagine that policymakers have determined the initial exchange rate $\bar{e}$ so that the system is stable, that is, it settles at point $E$. Unfortunately, any exogenous 
shock to output (favourable or not) pushes the system on a circular trajectory, and brings about costly fluctuations. A very powerful shock may even push the system on a very peripheral trajectory; in this case, there may be a significant risk that such a trajectory is not consistent with the condition $R>0$ and the currency board cannot survive. Of course, the dynamics put forward in this simple model depend on the specific form used to describe price and output formation. Other expressions may lead to more complex dynamics, where main variables follow explosive or chantic paths.

Finally, even under a currency board there is a money multiplier 11 and thus a risk of generalised run on banks. Furthermore, this risk is somehow higher than with a normal central bank, given that the currency board has little possibility to act as a lender of last resort (Berg and Borensztein, 2000; Gulde, Kähkönen and Keller, 2000). As argued by Chang and Velasco (2000), currency boards make balance-of-payment crises less likely only at the cost of making bank crises more likely. This should be seriously considered by policymakers in those countries that have fragile banking systems - as is the case of transition economies. And as put forward by Argentinean experience, even a country endowed with a currency board may face major liquidity risks, where foreign investors may refuse to roll over outstanding debt. In this case, the government may be forced to default, even if the long-run condition for solvency is satisfied (i.e. total debt is lower than the discounted value of future primary surpluses).

\subsection{Self-fulfilling prophecies and speculative attacks}

As the French experience of the early nineties has shown, even strong currencies may be subject to speculative attacks. Such logic would also justify attacks on currencies backed by currency boards. Standard explanations (Obstfeld 1984, 1992) develop on the logic of self-fulfilling prophecies (multiple equilibria). Basically, the decision to attack a currency is motivated by a large expected gain, that will materialise if the attack is actually undertaken. The scope for large expected gains results from the strong asymmetry between ex-post gains and losses of the speculators. Consider a speculator who borrows $1 \mathrm{mld}$ lei for one month and buys euros, while simultaneously he sells euros and buys lei in the one-month forward market. If at the end of that month the parity is unchanged, he will bear the transaction costs (and the interest rate), let say $1 \%$ of the principal. But if at the end of the month the leu has depreciated by $6 \%$, the speculator will have made a $5 \%$ gain, an equivalent of a $60 \%$ yearly interest rate. Even if the probability of the devaluation is of 0.5 , the domestic interest rate should increase by $30 \%$ in order to counter the attack. If the business sector cannot resist to this shock, devaluation is the only choice.

Of course, the action of one isolated speculator could not destabilise the currency. But what is optimal for one speculator should be optimal for many others, depending on their specific characteristics like the information set, wealth, and so on. Chances that a run on the currency occurs are more significant if the country is globally perceived to be in a position where it cannot sustain the parity. For instance,

\footnotetext{
${ }^{11}$ Let us assume that commercial banks hold a proportion $\phi$ of their deposits in the form of notes (themselves covered by dollars within the currency board): $N B=\phi D$. (For simplicity, we neglect here the banks deposits with the board). The public would also hold banknotes as a proportion $b$ of their deposits, $N P=b D$. The money stock is $M=N+D=N B+N P+D=(1+\phi+b) D$. Then, the ratio between the money stock and notes is $m=M / N=(1+\phi+b) /(\phi+b)$ higher than 1 . Thus, there is a strict relationship between the stock of foreign currency and the money stock. The smaller $\phi$ and $b$, the higher the multiplier is.
} 
if unemployment is high, the country might not be able to bear additional austerity in order to rebalance the current account Unfortunately, countries in Southeast Europe already reveal huge unemployment, $\frac{12}{2}$ and the accompanying social and economic pains will very likely be compounded when resolute steps toward the restructuring of their productive sector will be taken.

Forecasts of inflation in transition economies exceeding inflation in the EU often build on the Balassa-Samuelson paradigm (Halpern and Wyplosz, 1997). In this analytical framework, the small country economy is made up of a tradable and a nontradable sector, with labour as the only input. Prices in the EU, the "large country", are given. Under the law of one price, the prices of tradable goods in the small country are equal to prices in the Union, times the predetermined nominal exchange rate. Let us assume that this exchange rate was set initially such as the current account is balanced. Wages in the tradable sector can only increase in the small country when labour productivity increases in this sector. Then, with labour mobility between sectors, wages and prices in the non-tradable sector also increase, for constant productivity in that sector. The price level gradually increases with the catch-up in productivity. Of course, this kind of "adjustment" inflation would not affect the current account equilibrium. However, if private agents interpret the change in the equilibrium exchange rate as depending on relative changes in inflation rates in the consumer price index, they may feel that the currency is overvalued and the probability of speculative attacks may increase.

Therefore, if a country opts for a fixed exchange rate regime, either a standard one or a currency board, it may consider the case for capital controls that dissuade extensive short-term capital flows and increase the opportunity costs of speculative attacks (Krugman, 2000). While a Tobin tax may not be effective enough in dissuading short-term speculation (Kenen, 1995), the mechanism proposed by Eichengreen, Tobin and Wyplosz (1995) -- where foreigners who borrow domestic currency must constitute a one-year deposit -- could be effective.

\footnotetext{
${ }^{12}$ Unemployment rates in Southeast Europe are extremely high even by transition economies standards. Even if the size of the underground sector is considered unemployment rates of between 30-40\% (as in Macedonia, Serbia, Bosnia-Herzegovina, Kosovo, etc) are staggering.
} 


\section{SECOND PART: ROMANIA UNDER SCRUTINY}

\section{A basic introduction to the Romanian economic context}

From a macroeconomic perspective, Romania must solve two major problems before it can hope to be on the "short-list" of EU applicants. Firstly, it should bring inflation down radically, close to a one-digit level. With a yearly inflation rate of $40.6 \%$ in 1998 , of $55 \%$ in 1999 , and $40.7 \%$ in 2000 , Romania is far from matching the EU norm.

Another major problem for Romanian economy is its meagre growth performances. From data displayed in Figure 2 it can be seen that Romania has underperformed Central and Eastern Europe in a significant way.

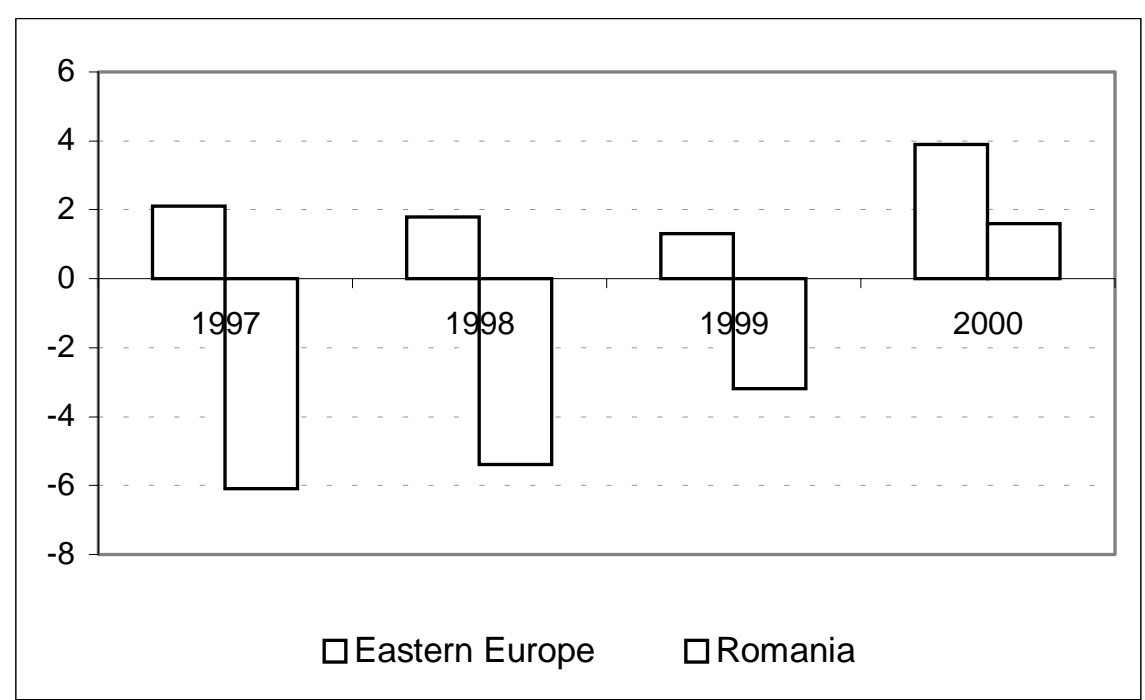

Figure 2. Annual growth rates in Romania and average growth rates in Central and Eastern Europe (the Baltics excepted). 1997 to 2000.

Source: Economic Survey of Europe, UN/ECE, 2001.

The unemployment rate also edged up, to reach a peak of $12.5 \%$ in February 2000 , although this figure cannot be readily interpreted as bad, if it can be associated to much needed firm restructuring. 


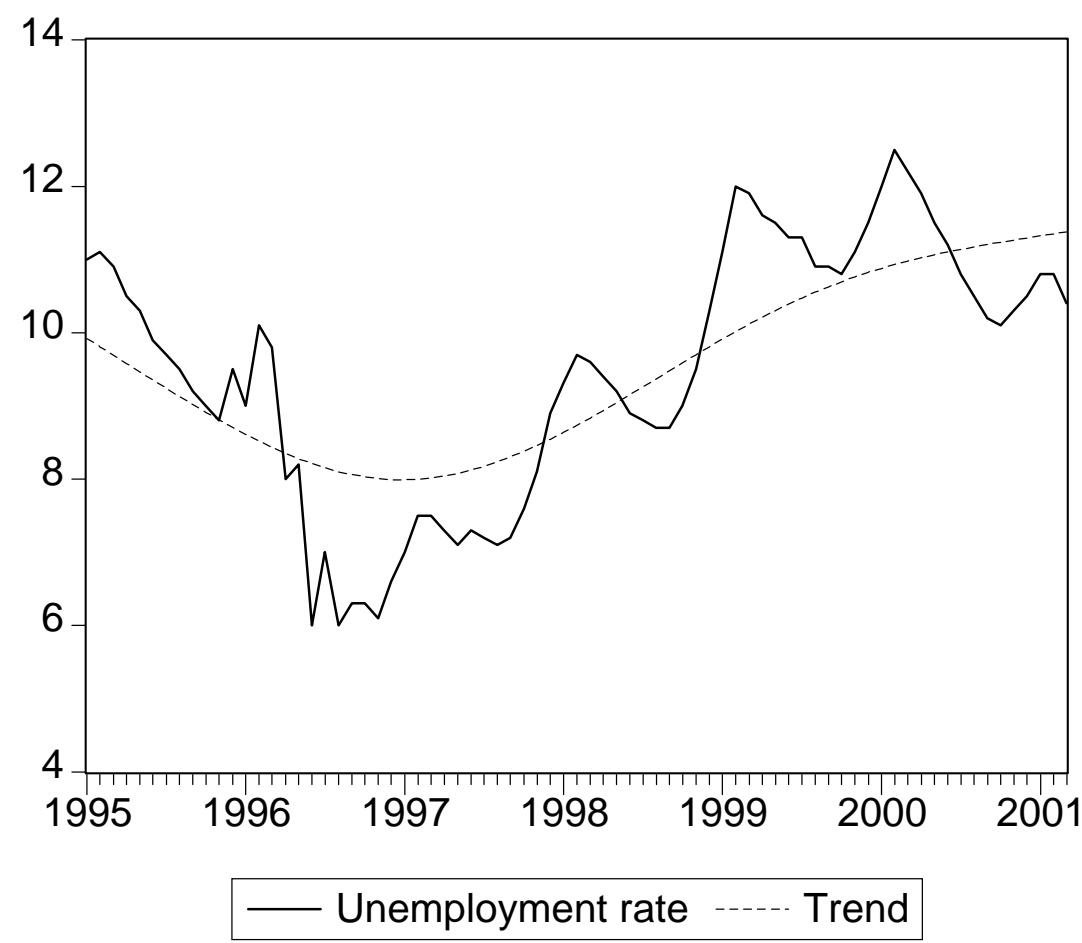

Figure 3. Unemployment rate, actual and trend (Hodrick and Prescott filter). January 1995 to March 2001. Source: NBR Monthly Statistical Bulletins

It is also worth mentioning that the Romanian current account balance was in deficit throughout this period; it reached 7.4\% of GDP in 1998 before the financial crisis, fell to $3.8 \%$ of GDP following the balance of payments adjustment of 1999, and stayed around 4\% of GDP in 2000. In early 2001 it started to grow again worryingly as output picked up. This large external imbalance is a signal of poor competitiveness of Romanian exports, and perhaps of an overvalued national currency (in real terms).

Clearly Romania has had major difficulties in achieving successful macrostabilisation. All through the nineties, when all other Central and Eastern European countries made significant progress in this respect, the situation in Romania stalled. How to explain this outcome? It is well known that there are fundamental relationships between the microeconomic structure of the economy, the institutions at work and the macroeconomic performances, but such a theory of comprehensive reform is beyond the scope of this study. We only comment on the role that the monetary and exchange rate mechanisms could have in improving the macroeconomic performance.

\section{The Romanian banking system}

A two-tier banking system was implemented in Romania at the end of 1990, made up of a central bank (the National Bank of Romania - NBR) and the credit institutions (or ordinary banks).

\subsection{Ordinary banks and the credit market}

Many of credit institutions which exist today took over the incumbent networks, already in operation under the central plan period. The most important network builds on the former local branches of the central bank itself; other networks come from the more specialized financial institutions, like the national investment 
bank or the bank for development of agriculture, etc. An important role in draining population savings was held by a specialized institution, which maintained a privileged status today. The postal service also created its own banking network. It is obvious now that in the early years of transition, these institutions lack dramatically the expertise to grant and manage credits in a decentralized economy. Even now, the shortage of skills is a main limitation of their development. In recent years some of these banks were privatised (e.g. BRD in 1997, Banca Agricola in 2001), in general being sold to well-known foreign banks. Some new private banks were also set up, mostly with foreign capital. And main international banks also opened branches in Romania, most often in Bucharest, but, for the time being, their credit activity is rather insignificant, being mostly concerned with portfolio investment. While the number of registered banks increases every year (they were forty by the end of 1999), only a few of them dispose of a countrywide network. In addition, there is a notorious lack of payment instruments (cheques, cards, not to speak of e-banking) and the payment mechanism is still rudimentary (but much better now than ten years ago). In the light of these elements, the Romanian banking sector appears quite underdeveloped. According to UNECE data, in 1999, the proportion of the broadmoney stock to GDP was of only $20.7 \%$ in Romania as compared to $42 \%$ in Hungary, $48 \%$ in Poland and as much as $71.07 \%$ in the Czech Republic (this proportion was of $49 \%$ in the United States or over $60 \%$ in the Euro Zone). In 1999, credit as a proportion of GDP represented only $12.6 \%$ in Romania, as compared to $22.9 \%$ in Hungary, 25.9\% in Poland and 59\% in the Czech Republic (UNECE, 2001).

\subsection{The central bank}

The National Bank of Romania is in charge of the monetary and foreign exchange policy. Its statute defines the main objective of the NBR as "to ensure stability of the domestic currency with a view to maintaining price stability" (Law 101/1998; Law 156/1999). Every year, the government and the NBR establish an inflation target, in general agreed with the IMF. For instance, the government target for 2001 is about $25-27 \%$. Unfortunately, year after year, the target has been largely missed.

The national currency is the Leu. While the leu is the only currency allowed for transactions in the domestic market, Romanian private agents (households and firms) may hold foreign currency denominated deposits with commercial banks.

Although a foreign exchange market was created in 1992, only in January 1997 a full-fledged foreign exchange rate market was set-up and the exchange rates were unified (UN/ECE, 1997). This unification reduced the government's room of manoeuvre for granting implicit subsidies via the official exchange rate. 13 By 1999 there were practically no restrictions on capital inflows; yet, outflows by residents require prior approval by NBR.

\footnotetext{
${ }^{13}$ See Daianu (2000) for a detailed analysis of the 1997 stabilisation programme.
} 


\begin{abstract}
Box: an unpleasant experience
In late 1991, against the background of a tough winter, the energy producing sector (made up of state owned firms) run out of foreign reserves needed to purchase coal and oil, and the Government and the NBR imposed that foreign exchange deposits of the enterprises be converted into lei deposits at the official (overvalued) rate, a move that deeply affected the confidence of private agents in the banking sector. In order to oppose the ensuing capital flight, a full-retention regime of foreign exchange was introduced in mid-1992. Administrative controls over the official exchange rate were maintained until the end of 1996, which led to the existence of three main exchange rates: an official rate for firms, which was fixed by the NBR; an implicit free rate set by firms, which used linked import and export transactions; and another free rate, for individuals. Most of this period, the official rate vas overvalued; cheap energy was an indirect way to subsidise energy intensive industries, but also contributed to a deterioration of the current account.
\end{abstract}

In mid-1999 the country faced major difficulties with the reimbursement of the foreign debt. The possibility of partial default was mentioned, but the crisis was avoided and the financial situation of the country improved soon afterwards. Arguably, the default was avoided due, also, ironically, to the underdevelopment of domestic financial markets (including the absence of a large stock of T-bills held by foreign investors, which can be explained by the non-functioning of a secondary market). In the spring of 2001, Standard \& Poor improved Romania's rating from Bto B. Actually, difficulties turn the other way round, as with steady capital inflows, some policymakers start fearing an excessive appreciation of the national currency that would hamper competitiveness. The good news was that the central bank was able to restore quite fast its reserves of foreign exchange, but at a cost (to be explained later on).

\title{
7. Money, the monetary base and the base multiplier
}

\subsection{Some relevant stylised facts}

In general, the money stock is defined in this text as M2. This aggregate includes cash in circulation, checkable (sight) deposits, time and saving deposits and other short-term contractual savings, as well as foreign currency denominated deposits. There are two distinctive features of the Romanian composition of M2 with respect to EU countries. The first is the existence of foreign currency denominated deposits: private agents may and do hold dollar (or other important currency) accounts. The second is the relative small size of checkable deposits as compared to cash. As already mentioned, this latter feature is a consequence and an indication of the atrophy of the Romanian banking sector in general.

The figure 4 below depicts the large increase in the money stock, which was roughly multiplied by a factor of seven in five years. Is this change due to an extensive development of bank credit, or to an increase in the monetary base with the

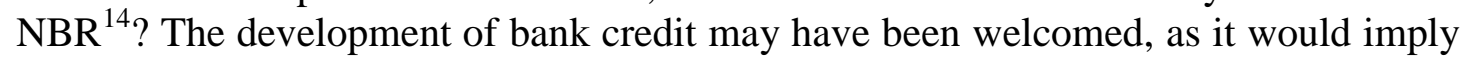
the development of the banking sector and the much needed financing of economic development. To provide an answer, we plot the base multiplier (i.e. the ratio between M2 and the monetary base) and the money stock M2 on the same graph. If in 19971998 the multiplier was relatively high, since 1999 it has gone back to its beginning-

\footnotetext{
${ }^{14}$ Monetary base includes cash (bank notes and coins) and banks deposits with the NBR (also called reserves).
} 
of-transition value of about $4 .{ }^{15}$ Clearly, the main responsible for increases in money stock are increases in the monetary base.

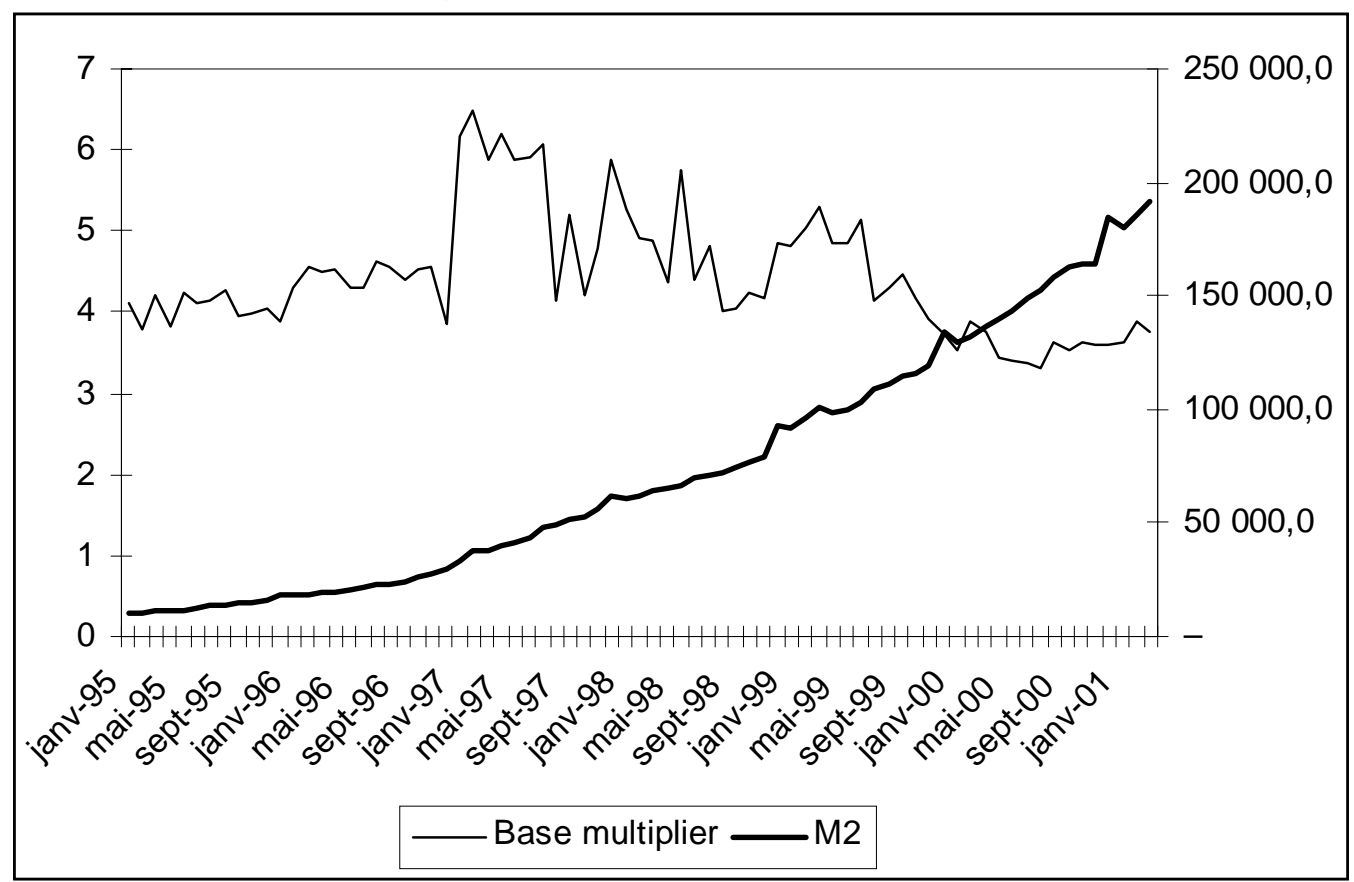

Figure 4. Money stock and the base multiplier. January 1995 to March 2001.

M2 is expressed in billion lei, right hand axis. Source: NBR, Monthly Statistical Bulletins.

\subsection{The structure of the base multiplier}

However, a deeper analysis of the multiplier could be useful. Let us consider that commercial banks hold as reserves (deposits at the central bank) a proportion $r<1$ of their deposits in lei and a proportion $\rho<1$ of their dollar denominated deposits. Banking regulation determines a minimum reserve requirement; in addition, banks in the developed world would hold some limited amount of excess reserves if the volatility of the flow of deposits were high! 16 Private agents would hold cash in proportion $b$ to their lei deposits, in keeping with their payment habits. They would also hold $d$ lei in dollar denominated deposits for every leu deposit (we assume for simplicity that people would not hold dollars cash, given that they cannot use it as such for transaction purposes and that dollars notes carry no interest $\frac{17}{17}$.

Let us denote by $D$ the lei deposits (to simplify, we make no difference between demand, time and savings deposits). The money stock is $M=$ Cash + Lei deposits $+\$$ deposits $=b D+D+d D=D(1+b+d)$. The money base is: $B=$ Cash + Reserves $=b D+r D+\rho d D=D(r+b+\rho d)$. The money multiplier is thus:

\footnotetext{
${ }^{15}$ One may point at the exceptional conditions in 1997, when inflation was $151 \%$ and real money supply plummeted; by comparison, 1997-1998 were like an intermezzo, to be followed by return to what seems to be normality in Romania - a money multiplier of around 4.

${ }^{16}$ Minimum reserves bear an interest rate fixed on a periodic base by the NBR (e.g, $25 \%$ on reserves build for lei deposits in July 2001). Excess reserves are remunerated at a much lower rate (for overnight deposits, the interest rate was $5 \%$ in July 2001).

${ }^{17}$ In practice, firms and individuals would use hard currency in cash for certain transactions, even if this is illegal. Transactions with VISA and other credit cards often are denominated directly in dollars.
} 


$$
m=M / B=\frac{1+b+d}{r+b+\rho d}>1
$$

It can be seen that the multiplier is a decreasing function in $b, r$ and $\rho$. That means that, ceteris paribus, increases in the reserve ratios would reduce the money stock. An increase in the public propensity to hold cash would also reduce the money stock. The impact of increased propensity to hold dollar denominated deposits is more ambiguous. The sign of the derivative:

$$
\frac{\partial m}{\partial d}=\frac{b(1-\rho)+(r-\rho)}{(r+b+\rho d)^{2}}
$$

is clearly positive if $r \geq \rho$, that is if the reserve ratio that applies to deposits in lei is larger than the reserve ratio that applies to dollar (and euro) deposits. Since August 1998 this condition is clearly fulfilled as the minimum reserve ratio were around $30 \%$ for lei and $20 \%$ for dollars (in July 2001, $r=27 \%$ and $\rho=20 \%$ ).

This configuration brings about additional volatility. If, for some reason, people lose confidence in the domestic currency, they would shift to dollar denominated deposits ( $d$ increases). This would raise the multiplier and the money supply, and would entail a decline in interest on lei deposits, which would ex-post validate the adverse "confidence" shock. On the contrary, if $\rho>(r+b) /(1+b)>r$, then the increase in the propensity to hold dollar deposits may have a stabilising effect in the event of credibility shocks.

The figure below depicts the time patterns of the ratios $b$ and $d$.

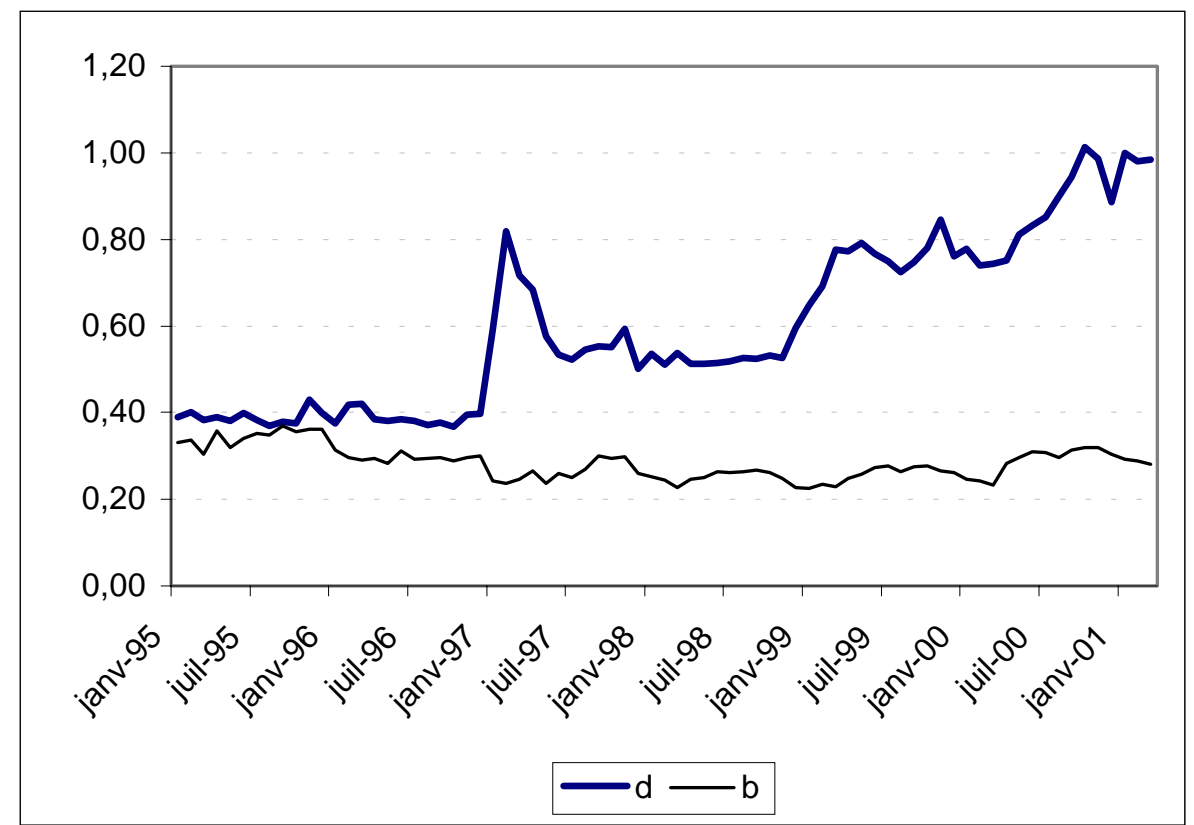

Figure 5. Propensity to hold cash and dollar deposits. January 1995 to March 2001.

Here $b$ is the ratio of cash outside banks to total lei deposits and $d$ is the ratio of dollar deposits (expressed in lei) to total lei deposits. Source: NBR, Monthly statistical bulletins and own calculations of the authors.

It can be seen that the propensity to hold lei in cash is rather stable after 1997, fluctuating around 0.25 . But the propensity to hold dollars has increased markedly, 
first in 1997, then after January 1999. Hence, the relative stability of the base multiplier in the late 1990s may be explained by a rise in compulsory and excess reserves.

So, given that the money multiplier has not risen steadily (currently, it gets back to its "historical" value), the large increase in the money stock should be analysed in close relation with positive variations in the monetary base. We know that the monetary base responds to countervailing changes in the central bank assets. In the following, we take a closer look to NBR assets.

\subsection{The NBR balance sheet: asset side}

The Table 1 below shows the main posts of the asset side of the balance sheet of the NBR: net foreign assets (foreign assets - liabilities) also called reserves of foreign exchange (RFX), credits to the government (mainly Treasury bonds) and credits to the banking sector. Normal credits to the banking sector are made up of genuine refinancing credits with a pure monetary purpose, and of a special credit line. The genuine refinancing operations are mainly realized through repo/reverse repo operations with one month maturity.

\begin{tabular}{|l|c|c|c|c|}
\hline & $\begin{array}{c}\text { Net foreign } \\
\text { assets }\end{array}$ & $\begin{array}{c}\text { Credit to the } \\
\text { government }\end{array}$ & $\begin{array}{c}\text { Normal credit } \\
\text { to the banking } \\
\text { sector }\end{array}$ & $\begin{array}{c}\text { Special credits } \\
\text { and other } \\
\text { bank funding }\end{array}$ \\
\hline December 1995 & -631 & 3562 & 4724 & 4552 \\
\hline December 1997 & 11425 & 3271 & 3366 & 7719 \\
\hline December 1999 & 29602 & 21411 & 2433 & 8696 \\
\hline December 2000 & 65858 & 16176 & 2296 & 13402 \\
\hline
\end{tabular}

Table 1. NBR main asset positions in billions of lei. Source: NBR.

As can be seen, between December 1997 and December 2000, the largest increases were recorded in the positions "Net foreign assets" and "Special credits and other bank funding".

These special credits deserve more scrutiny. Until 1997, state-owned banks often granted easy credits to various sectors (energy, agriculture, heavy industry, etc) and firms in trouble. They did it either following the reflexes of central planning and the instructions of the government, or as a result of obscure deals between their managers and various clients. Some banks also get involved in trouble affairs, financing dodgy projects, most notorious being the Bancorex case (the former socialist bank for foreign trade, which, after tearing down all its large amount of capital, accumulated large debts, then went bankrupt). Arguably, state support to banks would have limited the risk of a generalised failure of a too fragile banking system. One may nevertheless suspect that some vested interests may have motivated this decision too. Although the government took over a large amount of bad debts (Bancorex, Banca Agricola), the central bank was systematically solicited to bail out some of the banks that went in deep financial trouble (Dragulin and Radulescu, 2000). Some Romanian policymakers may have lived with the illusion that the measure "insulates" the public deficit. Actually, it led to an almost automatic monetization of what normally were public expenses. In addition, the NBR was asked to provide small savers in the failing banks with a minimum capital. Such a huge amount of "special" central bank credits (10000 billion lei by December 2000) clearly undermined the 
NBR main task of fighting inflation, given that, most of the time, all these credits translated into a larger money supply.

From Table 1 it can be seen that the most spectacular increase in NBR assets refers to the net reserves of foreign exchange. After the 1999 mini-crisis, the central bank bought large quantities of foreign currency and foreign currency denominated assets. Today the stock of foreign reserves looks satisfactorily (Figure 7). The strategy of buying dollars entailed a sharp increase in the monetary base and tested the ability and willingness of the NBR to sterilise excess liquidity. Two factors pushed towards this decision: on one hand, under IMF' nudging, Romania aimed to recover a "normal" stock of foreign reserves, to signal her credibility as an international borrower. On the other hand, NBR officials considered that the leu nominal depreciation was necessary in order to maintain export competitiveness. Both of these motivations are sensible, although one may be more ambivalent about the relationship between nominal depreciation and real depreciation in the high-inflation Romanian context, and also about the impact of a weak leu on export competitiveness in the long-run. It is also not very clear whether the speed of recovering the reserves was the most appropriate. On one hand, given the available sterilisation instruments, such a strong variation in NBR assets clearly brought about a huge increase in the monetary base; this increase fuelled the money stock and prices, and caused policy slippage which pushed inflation beyond its target. One can submit that a more gradual reserve recovery would have reduced policy slippage and better tempered inflation. On the other hand, in view of the recurrent emerging crises and the need to avert external shocks, the central bank's obsession with rebuilding its reserve stock at a rapid pace did make sense.

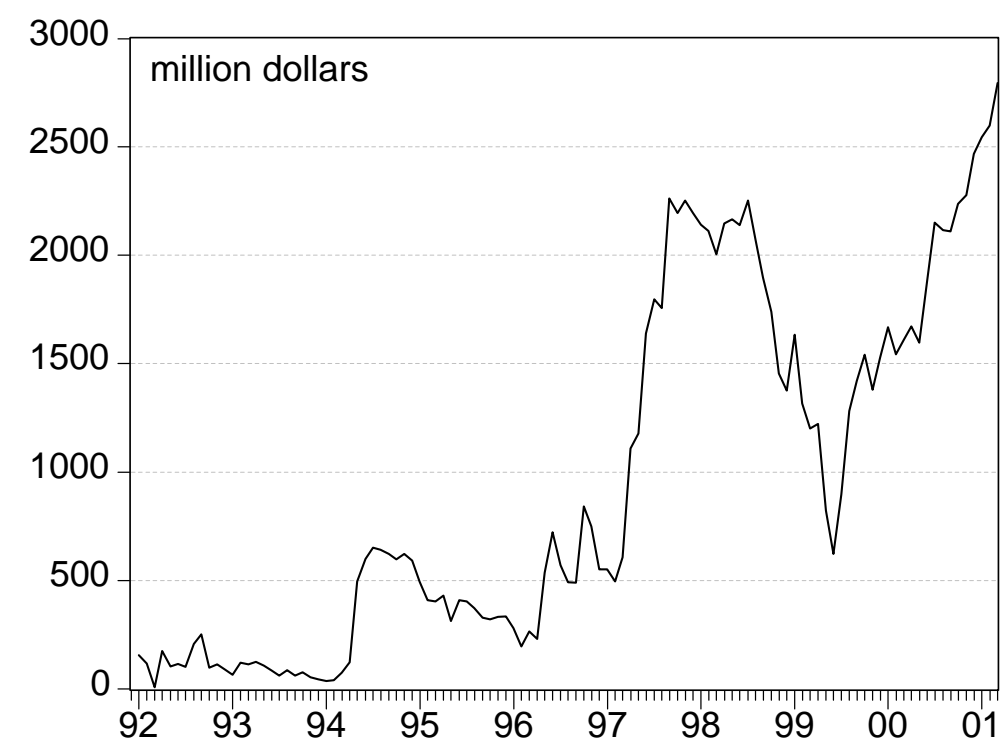

Figure 7: Gross foreign assets with the NBR in US dollar equivalent. January 1992 to March 2001. Source: NBR Monthly Bulletins

\subsection{Sterilization: NBR methods}

When a central bank intervenes in the foreign exchange market and acquires foreign currencies, it pushes towards (nominal) depreciation the domestic currency. But the increase in the assets of the central bank comes with an equivalent increase in its liabilities, more precisely of the reserves that ordinary banks held with the central 
bank. It ensues the multiplication of the monetary base, with an increase in deposits and the money supply in the economy. If this increase in the money stock translates itself in higher prices, in real terms the depreciation rate can be smaller than the nominal depreciation and may even turn into real appreciation. A country that runs a large current account deficit may wish to prevent this outcome. In this case, the central bank must block the increase in monetary base. It thus have to simultaneously carry out a sterilization operation, where it offsets the initial increase in reserves of foreign exchange (or net foreign assets) by a reduction in other counterpart of the monetary base. Let us examine a (very) simplified balance sheet of a "standard" central bank, like the Fed or the ECB:

Balance sheet of a “standard" central ball|
\begin{tabular}{|lll|ll|}
\hline Assets & & Liabilities \\
\hline RFX & +1 & N & \\
\hline REF & & R & +1 \\
(a) & -1 & & -1 \\
\hline TB & & & \\
(b) & $(-1)$ & \\
\hline
\end{tabular}

On the asset side, we have RFX, the reserves of foreign exchange, REF for ordinary banks refinancing (or credit to the banking sector) and Treasury bonds held by the Central bank. On the liability side, we have N, the bank notes in circulation and the reserves R, i.e deposits of the ordinary banks with the central bank.

If the Central bank buys dollars in amount of 1 local currency unit, reserves and assets increase. To counter the increase in reserves, two methods are usually utilized: (a) the bank may simultaneously sell Treasury bonds (this is the Fed privileged way) in the same amount, or (b) it may reduce the credit to the banking sector (REF) (this is the ECB preferred way). Both operations will lead to a unit reduction in the reserves $(\mathrm{R})$.

But let us turn back to the contemporary situation of the NBR. As we know, after the summer 1999 crisis, the NBR augmented dollar assets in a rapid and accelerated way. In order to prevent the increase in the monetary base, it was bound to sterilise this intervention.

Could the NBR have used the above-mentioned usual tools? Obviously, it could not have reduced refinancing, insofar Romanian refinancing of the banking sector is quite small, and is mostly related to non-monetary operations, where some banks received special credits to help them restructuring. It neither could sell massively Treasury bonds, first of all because the stock of Treasury bonds is quite small compared to foreign exchange reserves, and because there was quite little appetite for these bonds.

So the NBR used another method, where the NBR borrows resources from the ordinary banks. This operation is called "deposit-taking", or attracting deposits, and can be seen as the reverse of a refinancing operation. So far, the average duration of these operations were of one month, but the tendency is to lengthen them. In this case, the simplified balance sheet of an ordinary bank looks as: 
Balance sheet of bank $i$

\begin{tabular}{|c|c|}
\hline Assets & Liabilities \\
\hline $\mathrm{R}_{\mathrm{i}}$ & $\mathrm{D}_{\mathrm{i}}$ \\
\hline $\mathrm{A}_{\mathrm{i}}$ & $\mathrm{REF}_{\mathrm{i}}$ \\
\hline $\mathrm{C}_{\mathrm{i}}$ & \\
\hline
\end{tabular}

The bank holds reserves with the central bank $\left(\mathrm{R}_{\mathrm{i}}\right)$, lends to private agents $\left(\mathrm{C}_{\mathrm{i}}\right)$ and lends resources to the central bank $\left(\mathrm{A}_{\mathrm{i}}\right) . \mathrm{D}_{\mathrm{i}}$ are the deposits of private agent with this bank. Some ordinary banks have also benefited from restructuring credits or normal refinancing credits, denoted by $\mathrm{REF}_{\mathrm{i}}$.

The balance sheet of the NBR is :

Simplified balance sheet of NBR
\begin{tabular}{|l|lc|}
\hline Assets & Liabilities \\
\hline RFX +1 & N & \\
\hline REF & R & +1 \\
& & -1 \\
\hline TB & A & +1 \\
\hline
\end{tabular}

On the liability side, we have now total central bank borrowing from ordinary banks, in the amount A. We also have explained why the NBR has little margin for altering REF. Hence, in order to sterilize the increase in reserves, a 1 leu increase in RFX must be balanced by 1 leu increase in A (or a 1 leu reduction in TB).

If the initiative for buying dollars stays with the NBR, the initiative for lending money to the NBR stays with the ordinary banks. To be sure that the banks want to lend money, the NBR must offer an interest rate on these deposits higher than the interest rate that banks can obtain from lending in the private market. So far, the spread was about 10 percentage points.

Has the NBR carried out an effective sterilisation policy? Let us take a closer look to the figures. ${ }^{18}$ From the trough of April 1999 to April 2001, net foreign assets increased from 15600 billion lei to 82300 billion lei. In the meantime, net refinancing (genuine repo reverse/repo - attracted deposits) barely varied around 2000 billion lei. Only in October 1999, average outstanding attracted deposits rose sharply from 3000 billion lei to 7500 billion lei. But, throughout the year 2000, the NBR made little use of this tool. However, the reduction in the stock of Treasury bonds by over 5000 billion lei between December 1999 and December 2000 (Table 1) may be interpreted as an attempt to sterilise. The NBR seems now eager to recourse again to the deposittaking weapon, as, between March 2000 to February 2001 it increased by 6000 billion lei the average stock of attracted deposits.

So, if the NBR wants to push toward the real depreciation of the leu, it should continue to buy dollars and sterilise this intervention by attracting more and more deposits. Assuming that the bank has enough resources to pay the high interest rates needed to attract these deposits, what does such a policy entail? By offering high interest rates on attracted deposits, the NBR crowds out credits to the productive sector. While depreciation favours exporters, higher interest rates may harm investment, thus firms that produce for the domestic market face only the adverse effect. The aggregate effect is ambiguous.

\footnotetext{
${ }^{18}$ Such as published in the Monthly Bulletin 4/2001 of the NBR.
} 


\section{The exchange rate policy}

Since 1997 the leu fluctuates against the major currencies in a free market where the NBR intervenes as any other trader. However, the volume and the frequency of the transactions of the NBR in the foreign exchange market exceed what we normally can see as specific to a managed float regime. In mature market economies, the central bank resorts to interventions in the foreign exchange market only in exceptional cases, and tries to influence the exchange rate by monetary policy, in particular by managing short-term interest rates. But given that in Romania the Treasury bonds market is quite thin and the banking sector does not demand refinancing credits, the central bank has limited control over market determined shortterm interest rates. So, at a first sight, it seems that if the NBR wants to alter the international value of the leu, it can (and should) rely on direct transactions in the foreign exchange market. Let us take a closer look to this reasoning.

Figure 8 shows the evolution of the real exchange rate of the leu relatively to the US dollar since 1992. During the early years of transition, there was a general tendency of real appreciation of the leu. To a certain extent, such an evolution is consistent with the Balassa-Samuelson paradigm 19 , but an excessive appreciation would hamper export competitiveness. The structural current account deficit of Romania throughout the last decade would point to such a weakness. Moreover, the major difficulties faced by Romania in 1999 followed a period of sharp real appreciation, and the recovery was accompanied by depreciation. So, what matter for economic performance is not the dynamics of nominal, but of real exchange rates. In low an inflation environment the difference is not so sharp; but Romania is not a low inflation environment.

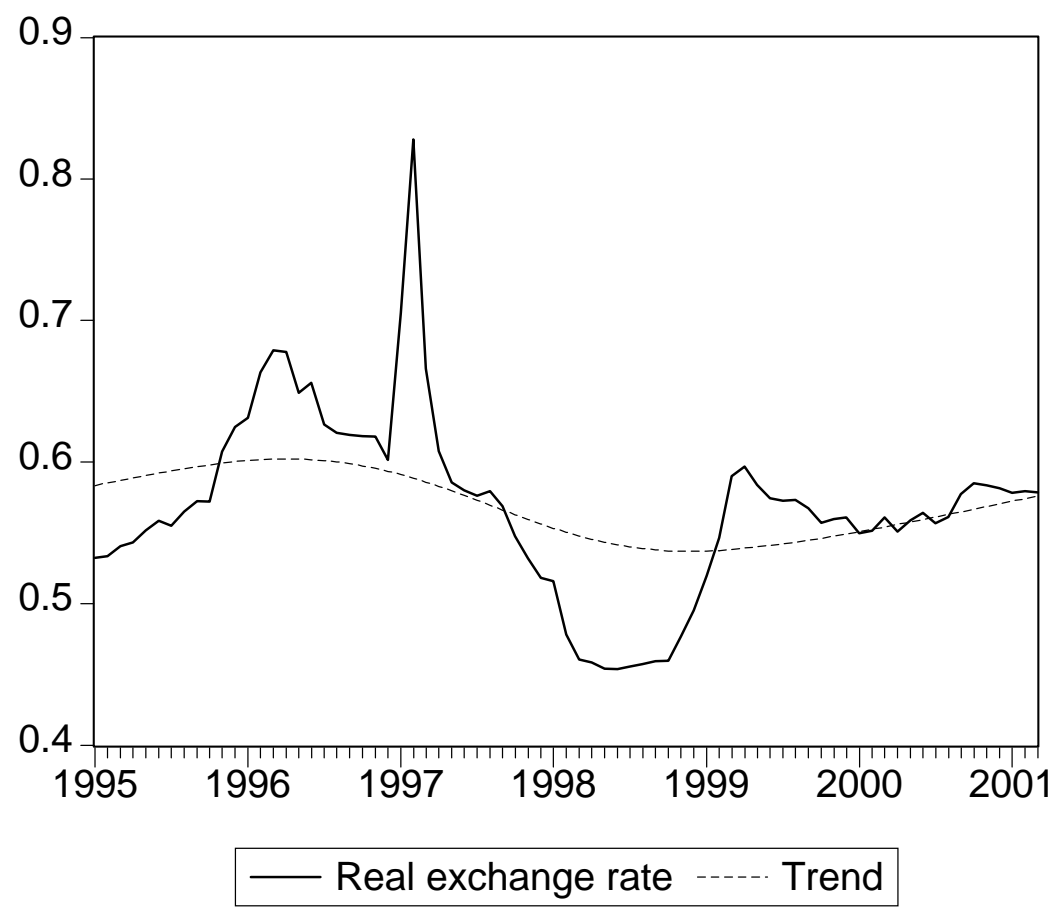

Figure 8. Real dollar-leu exchange rate index, base 1.00 in December 1991. The trend builds on Hodrick and Prescott filter. Price variation builds on consumer price indexes in Romania and the US. Source: NBR and US Bureau of Labour Statistics

\footnotetext{
${ }^{19}$ A note of caution should be kept in mind since rationing accompanied the functioning of the official foreign exchange market until early 1997.
} 
During the 1999 crisis, the NBR, instead of raising interest rates, bough lei massively (and sold reserves, as shown in Figure 7). This may have limited the size of the devaluation, but at the cost of a rising default risk on foreign debt due to reserve depletion.

\section{More empirical evidence on the devaluation - inflation relationship}

Let us consider more in depth the factors that contributed to the steady nominal devaluation of the leu. In Figure 9, it can be seen that the nominal exchange rate has evolved in pair with prices in the goods market.

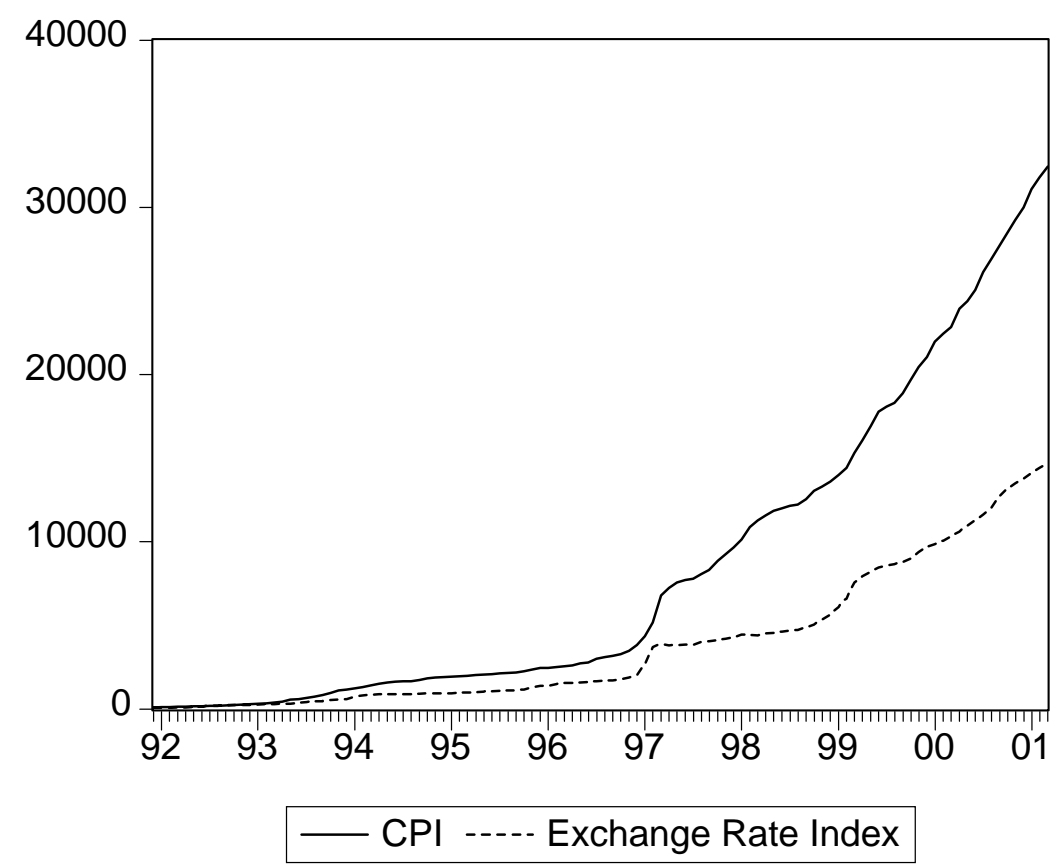

Figure 9. Nominal exchange rate and CPI Indexes (base 100 in December 1991). January 1992 to March 2001. Source: NBR

But has the leu depreciation been a major cause of price inflation or, as elementary monetarist logic would imply, the nominal devaluation only reflects, with a lag, the price increase? A Granger causality test tends to corroborate the former hypothesis, indicating that exchange rate hikes lead the rise in prices. But the monetarist logic is not completely falsified. A similar test run this time on inflation and money growth rate shows that the money growth rate also leads the price increase (see Appendix A for the two tests).

Of course, a theory of inflation for economies with a distorted microeconomic structure and lack of basic institutions like the Southeast European ones is difficult to work out. Therefore we limit ourselves to a basic empirical approach and develop a simple VAR model, considering the interplay between changes in prices, changes in the money stock and changes in the nominal exchange rate. Data are monthly, in the interval 01:1997 to 03:2001. We did not consider earlier data, as the exchange rate was not fully liberalized. Equations of the model are presented in the Appendix.

The response of the inflation rate to a shock in the money growth rate (DRM) and in the devaluation rate (DVN) is depicted in the figure below. As can be seen, a one standard deviation impulse in the former variables entails significant inflation acceleration (up to $1.5 \%$ per month inflation increase). The maximum impact is 
reached with a three-month lag for devaluation and a four-month lag for money. It takes some one-year to the system to return at the pre-shock equilibrium.

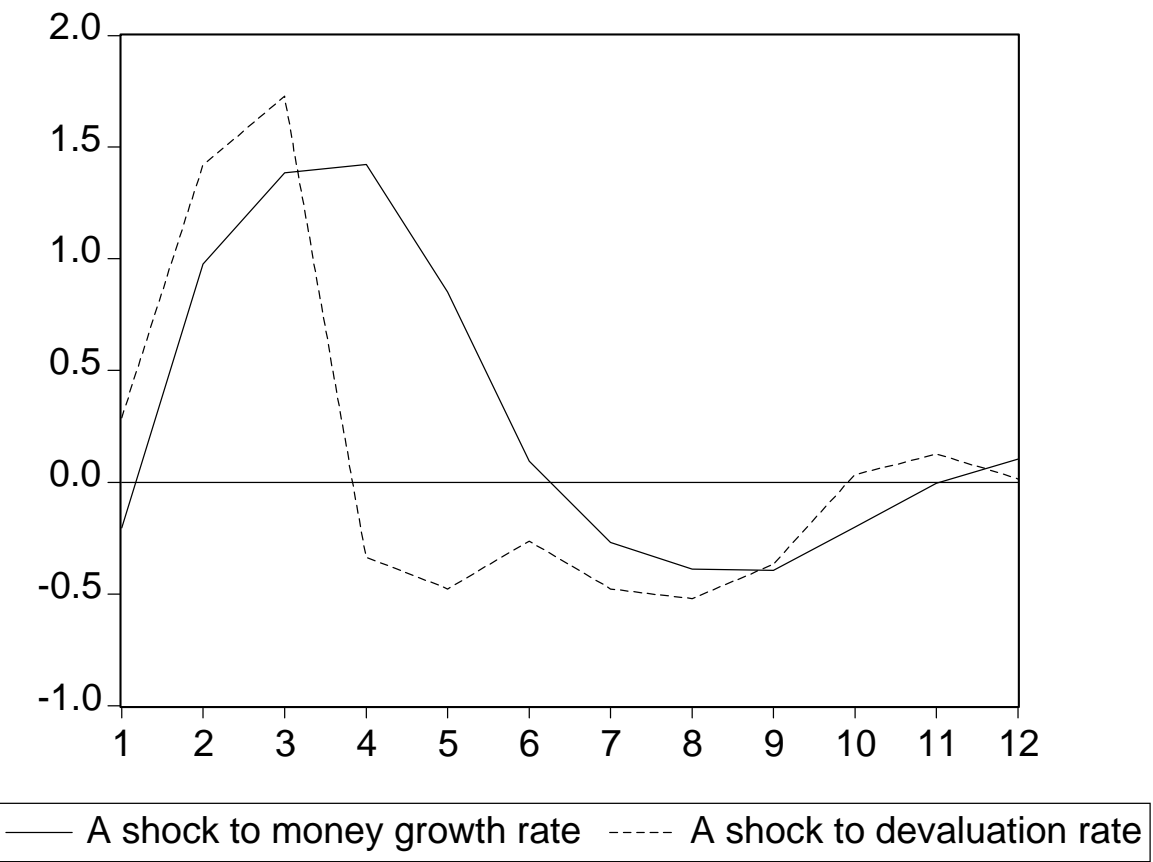

Figure 10. The impulse function. Response of monthly inflation rate to one standard deviation shock in the monthly money growth rate and in the devaluation rate. On the horizontal axis: number of months after the shock.

This simple AR model is instructive as it points to the high speed of transmitting nominal shocks in the Romanian economy. In mature monetary economies, money shocks need over six months to translate into higher prices. In Romania, the first impact can be observed only two months later.

This would point to a source of ineffectiveness of the NBR policy of managing real exchange rates by systematic interventions in the foreign exchange market over the 1997-2000 period. If the central bank buys dollars in an attempt to depreciate the leu, it simultaneously increases the money stock, which, two months later, already brings about higher inflation. In this context, the real depreciation is hard to be achieved. The massive recourse to sterilization is the only chance to block the increase in the money stock.

\section{Conclusion and policy implications for Romania}

Romania's macroeconomic performance can be termed so far as disappointing: the country has not been able to deliver steady growth, low unemployment and low inflation. Many factors are microeconomic and can be related to the slow progress with firm restructuring, privatisation and institution building. In the text at hand we have taken these important constraints as given, to focus on the effectiveness of monetary and exchange rate mechanisms and policies The National Bank of Romania has been, so far, unable to carry out a consistent monetary policy, which should subdue inflation. Under quite unfavourable circumstances and various pressures (frequently of a political nature) it has often provided easy credit to "sensible" sectors and dodgy commercial banks. Such quasi-fiscal operations have been a resilient feature of NBR's activity throughout the decade. At some moments, it also financed directly public deficits, in contradiction with the price stability goal. 
And it still carries out frequent and large interventions in the foreign exchange market, notably as a dollar buyer after 1999, another policy that leads to monetary base ballooning. We know that after 1999, sterilisation has become a major concern for the NBR, but it did not fully neutralise the increase in reserves of foreign exchange. This happened, seemingly, since the NBR programmed relatively high inflation targets (a substantial expansion of base money), and focused on a rapid recovery of foreign exchange reserves. The NBR's original sterilisation instrument, of deposit-taking, was utilised in various moments, and its effects were felt, especially, in the aftermath of the 1999 crisis. Now, the NBR has more than recovered the precrisis foreign exchange reserves and may cease buying dollars. This would limit further increases in the monetary base. But the NBR may wish to keep on buying dollars in order to force the real depreciation of the leu, in the context where Romanian current account deficits look too high. We know that in the long-run, export competitiveness may be gained only through firm restructuring and productivity gains. But in the short-run, real depreciation may help export-oriented firms to compete in the world market. In order to achieve this target and simultaneously fight inflation, sterilisation should be carried out much more vigorously than in the past. But this points to the risk of pushing interest rates higher, and crowding out domestic investment. Favouring export-oriented firms may harm domestic-oriented ones. Unfortunately, the aggregate effect of the policy is ambiguous. A better policy would involve a solid disinflation package, which would trigger re-monetisation, less sterilisation pressures and a competitive exchange rate in relation with productivity gains.

Therefore, what should be done to improve the operation of monetary policy in order to engage the disinflation process? Quite importantly, NBR monetary policy would have to be unburdened of quasi-fiscal operations. There has been substantial progress in this respect in recent years, but more has to be done. The central bank management should be insulated in his current tasks from any inference from the Parliament and the Government even if, quite normally, the NBR has to be fully accountable to the political representatives with respect to the achievement of the assigned objectives.

The NBR acquired a new constitution in recent years and new rules for conducting operations in money and capital markets were established in late April 2000. Although these rules contain a comprehensive list of instruments, most of them cannot be utilised in an efficient way in the Romanian context, characterised by an undeveloped banking sector and a thin market for Treasury bonds.

Indeed, the success of monetary policy management in Romania rests to a large extent with the banking sector. The contemporary situation, where for restricting the monetary base the central bank must become a net borrower from ordinary banks, points to the underdevelppment of the banking system, and to its incapacity to finance the productive sector. ${ }^{20}$ Time is needed to develop credit banks networks, to build infrastructure and acquire skills. And with time will also emerge trust between banks, their lenders and borrowers. Trust and expertise are basic preconditions for the credit market to take off. And then the NBR may be able to extend its repo financing of the banking sector, and thus set up a powerful mechanism for managing short-term interest rates. This is a long-term process, and it may take the full decade 2001-2010 to have it implemented.

\footnotetext{
${ }^{20}$ This may also signal the lack of worthy investment projects.
} 
Monetary policy reform should be embedded into a coherent policy-mix to be set up simultaneously; the latter would include incomes policy and low budget deficits, themselves grounded in a tight control and streamlining of public spending and the imposition of financial discipline on firms and households. Ceteris paribus, high deficits come with high interest rates, and call for a laxist monetary policy to offset this effect, though this policy has major pitfalls in an open economy. More competition in the goods and labour markets as well as effective anti-trust measures, by curbing the market power of dominant blocks of suppliers, would also work against additional and unwarranted price increases.

As an upshot, there is a dual challenge for the NBR, for monetary policy, in order to subdue inflation: to control liquidity (base money) effectively and to break powerful inflationary expectations after years of almost "programmed inflation". But expectations react to monetary policy changes. As long as major policy changes are not implemented, either because there is no political will or because of the lack of institutions and infrastructure, there can hardly be a decisive change in expectations.

What would be the suitable exchange rate mechanism to accompany the reform of monetary policy?

a) Should Romania give up an autonomous monetary policy and adopt a currency board? A currency board would, by its internal structure, put an end to quasi-fiscal operations and deficit monetization: both these actions have poisoned NBR activity in the nineties. Under a currency board, the scope for devaluation is almost negligible, especially if the choice of the initial parity is rigorous. However, the behaviour of the money stock is less predictable. If the only way to acquire foreign exchange reserves consisted in running a trade surplus, the scope for a destabilising outcome is very limited; a sustained trade surplus implies more money, higher prices and less competitiveness, which has an adverse effect on exports. But additional foreign exchange reserves may be brought by massive capital inflows, related to direct investment but also to more speculative investment. Such an institution is therefore not a "miracle" solution and its implementation would come with new risks. It may leave the country defenceless to adverse shocks that may hit the economy prior to EU integration. While it contains the government spending fervour by ruling out deficit monetization, it may favour excessive borrowing from abroad. This could lead to speculative lending and asset price inflation, with major financial risks. Even under a currency board, speculative attacks on the currency could occur, especially if the currency seems overvalued. In addition, potentially high real interest rates associated to a large foreign debt may strain fragile banks overwhelmingly.

b) A flexible exchange rate may avoid the accumulation of nominal imbalances and may provide for the needed flexibility to adjust to adverse shocks. The main advantage for Romania of implementing a genuine fullyfledged flexible exchange rate regime is its simplicity. This would allow policymakers to focus on short term goals as limiting the monetary base growth and stabilising the base multiplier. Whatever the objective of the central bank, low inflation or a stable exchange rate, a successful antiinflation policy calls for a severe tightening of monetary policy today. A tough monetary policy may come with some increase in interest rates and a 
currency appreciation, which will bring about an additional favourable impact on curbing inflation. The main shortcoming is a risk that the real appreciation entails a reduction in export competitiveness. True, in the long run, this may force firms to restructure and increase productivity. But in the close future, this policy may push out of the market an excessive number of firms, in the context where the Romanian economy is already very weak.

c) Should Romania adopt a crawling peg (against the euro) combined with a tough disinflation policy? To be effective, this policy change requires that (a) the Central Bank has all the political autonomy and technical ability to pursue such a policy, (b) an appropriate depreciation rate target is set, and, (c) in general, mutually consistent policies are adopted in the fiscal and structural realms. As the devaluation rate should not be lower than the inflation rate, sterilisation would be systematic, to prevent the excessive increase in the money stock. Simultaneously, one may consider the implementation of "soft" capital controls, essentially aimed at dissuading speculative attacks (Eichengreen, Tobin and Wyplosz, 1995; Krugman 2000). Finally, a public body should monitor the foreign debt of commercial banks and firms, in order to rule out excessive private borrowing in foreign exchange. Such prudential norms would limit the adverse impact of devaluation, via a balance sheet effect (Krugman, 2000). Of course, by the moment when the economy takes off and inflation is cut to normal values, the crawling peg regime could be replaced by a flexible one (as did Poland in 2000).

Our analysis has put forward some relevant elements of an analysis of the monetary and exchange rate policies in Romanian transition economy. The improvement of these policies is essential for achieving lasting and sustainable growth. In the light of this paper, it appears that subduing Romanian inflation is not an easy, but it is a possible task. The paper did not investigate whether the reduction in inflation should be abrupt or gradual. Most of our conclusions point toward the necessity of a gradual disinflation. This interesting topic is worth being addressed in a further research. 


\section{Appendix A. Main econometric tests}

\section{Granger causality tests:}

Sample: 1997:01 2001:03

Lags: 4

\begin{tabular}{lccc}
\hline \hline Null Hypothesis: & Obs & F-Statistic & Probability \\
\hline \hline DVN does not Granger Cause INF & 51 & 31.7794 & $3.3 \mathrm{E}-12$ \\
INF does not Granger Cause DVN & & 1.74375 & 0.15843 \\
\hline \hline & & & \\
Sample: $1997: 012001: 03$ & & & \\
Lags: 4 & Obs & F-Statistic & Probability \\
\hline \hline Null Hypothesis: & 51 & 5.45475 & 0.00125 \\
\hline \hline DRM does not Granger Cause INF & & 0.24376 & 0.91183 \\
INF does not Granger Cause DRM & $=$
\end{tabular}

\section{The VAR ESTIMATE}

Included observations: 51

Standard errors \& t-statistics in parentheses

\begin{tabular}{|c|c|c|c|}
\hline & DRM & INF & DVN \\
\hline $\operatorname{DRM}(-1)$ & $\begin{array}{r}-0.269374 \\
(0.17023) \\
(-1.58239)\end{array}$ & $\begin{array}{l}0.113136 \\
(0.08314) \\
(1.36074)\end{array}$ & $\begin{array}{l}0.540687 \\
(0.20360) \\
(2.65569)\end{array}$ \\
\hline DRM(-2) & $\begin{array}{r}-0.125972 \\
(0.18591) \\
(-0.67758)\end{array}$ & $\begin{array}{l}0.089478 \\
(0.09080) \\
(0.98542)\end{array}$ & $\begin{array}{l}0.263304 \\
(0.22235) \\
(1.18418)\end{array}$ \\
\hline $\operatorname{DRM}(-3)$ & $\begin{array}{l}0.094973 \\
(0.17674) \\
(0.53737)\end{array}$ & $\begin{array}{l}0.190977 \\
(0.08632) \\
(2.21242)\end{array}$ & $\begin{array}{l}0.429138 \\
(0.21138) \\
(2.03021)\end{array}$ \\
\hline DRM(-4) & $\begin{array}{r}-0.170300 \\
(0.19578) \\
(-0.86988)\end{array}$ & $\begin{array}{l}0.121228 \\
(0.09562) \\
(1.26783)\end{array}$ & $\begin{array}{r}-0.243264 \\
(0.23414) \\
(-1.03895)\end{array}$ \\
\hline $\operatorname{INF}(-1)$ & $\begin{array}{l}0.531374 \\
(0.29812) \\
(1.78240)\end{array}$ & $\begin{array}{l}0.113846 \\
(0.14561) \\
(0.78187)\end{array}$ & $\begin{array}{l}1.153003 \\
(0.35655) \\
(3.23376)\end{array}$ \\
\hline $\operatorname{INF}(-2)$ & $\begin{array}{l}0.210050 \\
(0.29914) \\
(0.70218)\end{array}$ & $\begin{array}{l}0.439586 \\
(0.14610) \\
(3.00876)\end{array}$ & $\begin{array}{r}-0.394660 \\
(0.35777) \\
(-1.10312)\end{array}$ \\
\hline $\operatorname{INF}(-3)$ & $\begin{array}{r}-0.040200 \\
(0.31606) \\
(-0.12719)\end{array}$ & $\begin{array}{l}0.080365 \\
(0.15436) \\
(0.52061)\end{array}$ & $\begin{array}{r}-0.547886 \\
(0.37800) \\
(-1.44943)\end{array}$ \\
\hline $\operatorname{INF}(-4)$ & $\begin{array}{l}0.083056 \\
(0.16214) \\
(0.51225)\end{array}$ & $\begin{array}{r}-0.166512 \\
(0.07919) \\
(-2.10269)\end{array}$ & $\begin{array}{r}-0.174799 \\
(0.19392) \\
(-0.90141)\end{array}$ \\
\hline $\operatorname{DVN}(-1)$ & $\begin{array}{l}0.187730 \\
(0.14123) \\
(1.32921)\end{array}$ & $\begin{array}{l}0.370855 \\
(0.06898) \\
(5.37628)\end{array}$ & $\begin{array}{l}0.642119 \\
(0.16891) \\
(3.80146)\end{array}$ \\
\hline
\end{tabular}


William Davidson Institute Working Paper 402

\begin{tabular}{lrrr} 
DVN(-2) & -0.451075 & 0.088373 & -1.122129 \\
& $(0.19446)$ & $(0.09497)$ & $(0.23257)$ \\
& $(-2.31967)$ & $(0.93050)$ & $(-4.82496)$ \\
DVN(-3) & -0.060201 & -0.337543 & 0.324704 \\
& $(0.23174)$ & $(0.11318)$ & $(0.27715)$ \\
& $(-0.25978)$ & $(-2.98230)$ & $(1.17157)$ \\
& & & \\
DVN(-4) & -0.022689 & -0.006829 & 0.285285 \\
& $(0.21980)$ & $(0.10735)$ & $(0.26288)$ \\
& $(-0.10322)$ & $(-0.06362)$ & $(1.08523)$ \\
& & & \\
& 3.544747 & -0.325308 & -0.393529 \\
& $(1.39562)$ & $(0.68163)$ & $(1.66914)$ \\
\hline \hline R-squared & $(2.53992)$ & $(-0.47725)$ & $(-0.23577)$ \\
Adj. R-squared & 0.243440 & 0.877572 & 0.652183 \\
Sum sq. resids & 0.004527 & 0.838911 & 0.542346 \\
S.E. equation & 595.7297 & 142.1075 & 852.1244 \\
F-statistic & 3.959432 & 1.933823 & 4.735433 \\
Log likelihood & 1.018948 & 22.69895 & 5.937736 \\
Akaike AIC & -135.0439 & -98.49720 & -144.1715 \\
Schwarz SC & 5.805642 & 4.372439 & 6.163588 \\
Mean dependent & 6.298069 & 4.864865 & 6.656014 \\
S.D. dependent & 3.752162 & 4.347059 & 4.175222 \\
\hline \hline
\end{tabular}




\section{References}

Barro, Robert and David M. Gordon, (1983), "Rules, discretion and reputation in a model of monetary policy", Journal of Monetary Economics, 12, pp. 101-121.

Berg, Andrew and Eduardo Borensztein, 2000, "The pros and cons of full dollarization", IMF Working Paper WP/00/50.

Besancenot, Damien, Radu Vranceanu and Thiery Warin, 2000, "Pays de 1'Est: le coût d'une candidature à l'UEM", Economie Internationale, 81, pp. 65-76.

Blanchard, Olivier, 1997, “The Economics of transition”, Oxford, Clarendon Press.

Bleaney, Michael, 1999, "Price and monetary dynamics under alternative exchange rate regimes", IMF Working Paper WP/99/67.

Calvo, Guillermo A. and Carmen M. Reinhart, 2000, "Fear of Floating”, Mimeo, University of Maryland.

Chang, Roberto and Andrés Velasco, 2000, "Exchange-rate policy for developing countries", American Economic Review, 90, 2, pp. 71-75.

Daianu, Daniel, 1994, "Inter-enterprise arrears in a post-command economy", IMF Working Paper, 54/94.

Daianu, Daniel, 2000, "Structure, strain and macroeconomic dynamic in Romania", in C. Rühl and D. Daianu eds., Economic Transition in Romania, CEROPE and the World Bank, Arta Grafica, Bucarest, pp. 5-35.

Daianu, Daniel and Radu Vranceanu, 2000, "Pitfalls of taxation policy in transition economies," Acta Oeconomica, 51, 1, pp. 3-15.

Dragulin, Ion and Eugen Radulescu, 2000, "Monetary policy in Romania: challenges and options", in C. Rühl and D. Daianu eds, Economic Transition in Romania, CEROPE and the World Bank, Arta Grafica, Bucarest, pp. 457-476.

Eichengreen, Barry, James Tobin, and Charles Wyplosz, 1995, "Two cases for sand in the wheels of international finance", Economic Journal, 105, pp. 162-172.

Flood, Robert and Nancy Marion, 1999, "Perspectives on the recent currency crises literature", International Journal of Finance and Economics, 4, pp 1-26.

Flood, Robert and Peter Garber, 1984, "Collapsing exchange rate regimes: some linear examples", Journal of International Economics, 17, pp. 1-13

Friedman, Milton, 1953, Essays in Positive Economics, University of Chicago Press, Chicago.

Gulde, Anne-Marie, Juha Kähkönen and Peter Keller, 2000, "Pros and cons of currency board arrangements in the lead-up to EU accession and participation in the Euro zone", IMF Discussion Paper, PDP/00/1.

Halpern, Laszlo and Charles Wyplosz, (1997), "Equilibrium Exchange Rates in Transitional Economies", IMF Staff Papers, 44, 4, pp. 430-451.

Kenen, Peter, 1995, "Capital controls, the EMS and EMU”, Economic Journal, 105, pp. 181-192. 
Krugman, Paul, 2000, "Crises: The price of globalisation?", Paper presented at the 2000 Symposium on Global Economic Integration, Federal Reserve Bank of Kansas City.

Krugman, Paul, 1979, “A model of balance of payment crises, Journal of Money, Credit and Banking, 11, pp. 311-325.

Kydland, Finn and Edward C. Prescott, 1977, "Rules rather than discretion. The inconsistency of optimal plans", Journal of Political Economy, 85, 3, pp. 473492.

Layard, Richard, Stephen Nickell and Richard Jackman, 1991, Unemployment. Macroeconomic Performances and the Labour Market, Oxford University Press, UK.

LeBaron, Blake and Rachel McCulloch, 2000, "Floating, fixed or super-fixed? Dollarization joins the menu of exchange rate options", American Economic Review, 90, 2, pp. 34-37.

Miller, Jeffery B., 1999, "The currency board in Bulgaria. The first two years", Bulgarian National Bank Discussion Papers; DP/11/99.

Pinto, Brian, Vladimir Drebentsov and Alexander Morozov, 2000, "Give growth and macro stability in Russia a chance: Harden budgets by dismantling nonpayments", World Bank Policy Research Paper 2324.

Rivera-Batiz, Luis A. and Amadou N. R. Sy, 2000, "Currency boards, credibility, and macroeconomic behaviour", IMF Working Paper WP/00/97.

Rodrik, Dani, 1999, "Institutions for High-Quality Growth: What They Are and How to Acquire Them", 14 October, 1999, Paper prepared for the IMF Conference on Second Generation Reforms.

Salant, Stephen and Henderson, Dale, 1978, "Market anticipation of government policy and the price of gold", Journal of Political Economy, 86, pp. 627-648.

Samuelson, Paul A. and Robert M. Solow, 1960, "Analytical aspects of anti-inflation policy”, American Economic Review, 50, 5, pp. 177-194.

Stiglitz, Joseph E. 1999, "Whither Reform? Ten Years of Transition", paper presented at the ABCDE Conference of the World Bank, April 28-30, Washington DC.

UN/ECE, 1997, Economic Survey of Europe in 1996-1997, UN Economic Commission for Europe, Geneva, Switzerland.

UN/ECE, 2001, Economic Survey of Europe 2001, Vol.1, UN Economic Commission for Europe, Geneva, Switzerland. 


\section{DAVIDSON INSTITUTE WORKING PAPER SERIES - Most Recent Papers}

The entire Working Paper Series may be downloaded free of charge at: www.wdi.bus.umich.edu

CURRENT AS OF 11/13/01

\begin{tabular}{|c|c|c|}
\hline Publication & Authors & Date \\
\hline $\begin{array}{l}\text { No. 402: Subduing High Inflation in Romania. How to Better Monetary } \\
\text { and Exchange Rate Mechanisms? }\end{array}$ & $\begin{array}{l}\text { Daniel Daianu and Radu } \\
\text { Vranceanu }\end{array}$ & Aug. 2001 \\
\hline $\begin{array}{l}\text { No. 401: The Gender Wage Gap in Bulgaria: A Semiparametric } \\
\text { Estimation of Discrimination }\end{array}$ & Dean Jolliffe & July 2001 \\
\hline $\begin{array}{l}\text { No. 400: Do External Auditors Perform a Corporate Governance Role in } \\
\text { Emerging Markets? Evidence from East Asia }\end{array}$ & Joseph P. H. Fan and T.J. Wong & Oct. 2001 \\
\hline $\begin{array}{l}\text { No. 399: Financial Conditions and Investment during the Transition: } \\
\text { Evidence from Czech Firms }\end{array}$ & Lubomír Lízal and Jan Svejnar & Oct. 2001 \\
\hline $\begin{array}{l}\text { No. 398: Accessible Pareto-Improvements: Using Market Information to } \\
\text { Reform Inefficiencies }\end{array}$ & Michael Mandler & May 2001 \\
\hline No. 397: The Making of an Integrated National Grain Market in China & Wubiao Zhou & Oct. 2001 \\
\hline No. 396: Corruption and Resource Allocation: Evidence from China & Wei Li & June 2001 \\
\hline $\begin{array}{l}\text { No. 395: Government Shareholding and the Value of China's Modern } \\
\text { Firms }\end{array}$ & Lihui Tian & Apr. 2001 \\
\hline No. 394: Labor Hoarding in Russia: Where Does it Come from? & $\begin{array}{l}\text { Rouslan Koumakhov and Boris } \\
\text { Najman }\end{array}$ & June 2000 \\
\hline $\begin{array}{l}\text { No. 393: Ownership Structure, Corporate Governance, And Firm Value: } \\
\text { Evidence from the East Asian Financial Crisis }\end{array}$ & Michael Lemmon and Karl Lins & Apr. 2001 \\
\hline No. 392: Marshall and Labour Demand in Russia: Going Back to Basics & $\begin{array}{l}\text { Jozef Konings and Hartmut } \\
\text { Lehmann }\end{array}$ & Aug. 2001 \\
\hline No. 391: Economic Transition and Elections in Poland & $\begin{array}{l}\text { John E. Jackson, Jacek Klich, and } \\
\text { Krystyna Poznańska }\end{array}$ & June 2001 \\
\hline $\begin{array}{l}\text { No. 390: Effects of Bank Insolvency and Strategic Uncertainty on } \\
\text { Corporate Restructuring in Transition Economies }\end{array}$ & Christa Hainz & Aug. 2001 \\
\hline No. 389: Mark-Up Pricing In Bulgarian Manufacturing & $\begin{array}{l}\text { Rumen Dobrinsky, Boyko } \\
\text { Nikolov, and Nikolay Markov }\end{array}$ & June 2001 \\
\hline $\begin{array}{l}\text { No. } 388 \text { Globalization and Firms' Financing Choices: } \\
\text { Evidence from Emerging Economies }\end{array}$ & $\begin{array}{l}\text { Sergio Schmukler and Esteban } \\
\text { Vesperoni }\end{array}$ & May 2001 \\
\hline $\begin{array}{l}\text { No. } 387 \text { The Distributional Impacts of Indonesia's Financial Crisis on } \\
\text { Household Welfare: A "Rapid Response" Methodology }\end{array}$ & $\begin{array}{l}\text { Jed Friedman and James } \\
\text { Levinsohn }\end{array}$ & Sept. 2001 \\
\hline $\begin{array}{l}\text { No. } 386 \text { Corporate Financial Policies and Performance Prior to Currency } \\
\text { Crises }\end{array}$ & $\begin{array}{l}\text { Arturo Bris, Yrjö Koskinen, and } \\
\text { Vicente Pons }\end{array}$ & June 2001 \\
\hline No. 385 Ownership and Productive Efficiency: Evidence from Estonia & Derek C. Jones and Niels Mygind & Aug. 2001 \\
\hline $\begin{array}{l}\text { No. } 384 \text { Forthcoming in: Journal of Economic Perspectives, } \\
\text { "Institutional Determinants of Labor Reallocation in Transition" Vol. } \\
\text { 16, No. 2, Feb. } 2002 .\end{array}$ & Tito Boeri and Katherine Terrell & June 2001 \\
\hline $\begin{array}{l}\text { No. } 383 \text { Deindustrialisation and Structural Change During the Post- } \\
\text { Communist Transition }\end{array}$ & $\begin{array}{l}\text { Tomasz Mickiewicz and Anna } \\
\text { Zalewska }\end{array}$ & June 2001 \\
\hline No. 382 Markets and Growth & Štěpán Jurajda and Janet Mitchell & July 2001 \\
\hline $\begin{array}{l}\text { No. } 381 \text { Labor Market Discrimination During Post-Communist } \\
\text { Transition: A Monopsony Approach to the Status of Latvia's Russian } \\
\text { Minority }\end{array}$ & Robert S. Chase & Sept. 2000 \\
\hline No. 380 Dollarization of Liabilities in Non-tradable Goods Sector & Frédéric Chabellard & June 2001 \\
\hline $\begin{array}{l}\text { No. } 379 \text { Lessons from the Russian Meltdown: The Economics of Soft } \\
\text { Legal Constraints }\end{array}$ & Enrico Perotti & Mar. 2001 \\
\hline No. 378 Effective Tax Rates in Transition & Vlad Ivanenko & May 2001 \\
\hline $\begin{array}{l}\text { No. } 377 \text { Some Explanations for Changes in the Distribution of } \\
\text { Household Income in Slovakia: } 1988 \text { and } 1996\end{array}$ & $\begin{array}{l}\text { Thesia Garner and Katherine } \\
\text { Terrell }\end{array}$ & May 2001 \\
\hline
\end{tabular}

